\title{
Article
}

\section{Racecadotril for acute diarrhoea in children}

Liang, Yi, Zhang, Lingli, Zeng, Linan, Gordon, Morris and Wen, Jin Available at https://clok.uclan.ac.uk/31217/

Liang, Yi, Zhang, Lingli, Zeng, Linan, Gordon, Morris orcid iconORCID: 00000002-1216-5158 and Wen, Jin (2019) Racecadotril for acute diarrhoea in children. Cochrane Database of Systematic Reviews .

It is advisable to refer to the publisher's version if you intend to cite from the work. http://dx.doi.org/10.1002/14651858.cd009359.pub2

For more information about UCLan's research in this area go to http://www.uclan.ac.uk/researchgroups/ and search for < name of research Group>.

For information about Research generally at UCLan please go to http://www.uclan.ac.uk/research/

All outputs in CLoK are protected by Intellectual Property Rights law, including Copyright law. Copyright, IPR and Moral Rights for the works on this site are retained by the individual authors and/or other copyright owners. Terms and conditions for use of this material are defined in the policies page.

\section{CLoK}

Central Lancashire online Knowledge www.clok.uclan.ac.uk

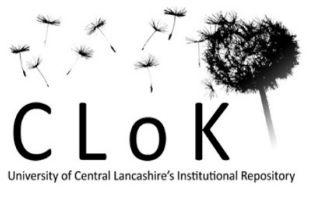


Cochrane Database of Systematic Reviews

\section{Racecadotril for acute diarrhoea in children (Review)}

Liang Y, Zhang L, Zeng L, Gordon M, Wen J

Liang Y, Zhang L, Zeng L, Gordon M, Wen J.

Racecadotril for acute diarrhoea in children.

Cochrane Database of Systematic Reviews 2019, Issue 12. Art. No.: CD009359.

DOI: 10.1002/14651858.CD009359.pub2. 
TABLE OF CONTENTS

HEADER

ABSTRACT

PLAIN LANGUAGE SUMMARY

SUMMARY OF FINDINGS

BACKGROUND

OBJECTIVES

METHODS

RESULTS

Figure 1.

Figure 2.

Figure 3.

Figure 4.

Figure 5.

Figure 6.

Figure 7.

Figure 8.

Figure 9.

DISCUSSION

AUTHORS' CONCLUSIONS

ACKNOWLEDGEMENTS

REFERENCES

CHARACTERISTICS OF STUDIES

DATA AND ANALYSES

Analysis 1.1. Comparison 1 Racecadotril versus placebo/no treatment, Outcome 1 Failure of rehydration.

Analysis 1.2. Comparison 1 Racecadotril versus placebo/no treatment, Outcome 2 Number of stools within 24 hours.

Analysis 1.3. Comparison 1 Racecadotril versus placebo/no treatment, Outcome 3 Number of stools between 24 to 48 hours.

Analysis 1.4. Comparison 1 Racecadotril versus placebo/no treatment, Outcome 4 Stool output within $24 \mathrm{~h}$.

Analysis 1.5. Comparison 1 Racecadotril versus placebo/no treatment, Outcome 5 Stool output within 48h.

Analysis 1.6. Comparison 1 Racecadotril versus placebo/no treatment, Outcome 6 Adverse events.

ADDITIONAL TABLES

APPENDICES

CONTRIBUTIONS OF AUTHORS

DECLARATIONS OF INTEREST

SOURCES OF SUPPORT

DIFFERENCES BETWEEN PROTOCOL AND REVIEW 
[Intervention Review]

\section{Racecadotril for acute diarrhoea in children}

Yi Liang1,2,3,4, Lingli Zhang1,2,3, Linan Zeng1,2,3, Morris Gordon5, Jin Wen6

1Department of Pharmacy, West China Second University Hospital, Sichuan University, Chengdu, China. ${ }^{2}$ Evidence-Based Pharmacy Center, West China Second University Hospital, Sichuan University, Chengdu, China. ${ }^{3}$ Key Laboratory of Birth Defects and Related Diseases of Women and Children (Sichuan University), Ministry of Education, Chengdu, China. ${ }^{4}$ Health Outcomes Division, College of Pharmacy, The University of Texas at Austin, Austin, Texas, USA. ${ }^{5}$ School of Medicine, University of Central Lancashire, Preston, UK. 6Department of Hospital Management and Health Policy, West China Hospital, Sichuan University, Chengdu, China

Contact address: Lingli Zhang, Department of Pharmacy, West China Second University Hospital, Sichuan University, No. 20, Section Three, Ren Min Nan Lu Avenue, Chengdu, Sichuan, 610041, China. zhanglingli@scu.edu.cn.

Editorial group: Cochrane Infectious Diseases Group

Publication status and date: New, published in Issue 12, 2019.

Citation: Liang Y, Zhang L, Zeng L, Gordon M, Wen J. Racecadotril for acute diarrhoea in children. Cochrane Database of Systematic Reviews 2019, Issue 12. Art. No.: CD009359. DOI: 10.1002/14651858.CD009359.pub2.

Copyright (C) 2019 The Authors. Cochrane Database of Systematic Reviews published by John Wiley \& Sons, Ltd. on behalf of The Cochrane Collaboration. This is an open access article under the terms of the Creative Commons Attribution-Non-Commercial Licence, which permits use, distribution and reproduction in any medium, provided the original work is properly cited and is not used for commercial purposes.

\section{A B S T R A C T}

\section{Background}

Acute diarrhoea is a leading cause of death for children under five years of age. Most deaths are caused by excessive fluid and electrolyte losses. Racecadotril is an anti-secretory drug that has been used for acute diarrhoea in children as an adjunct to oral rehydration therapy.

\section{Objectives}

To assess the efficacy and safety of racecadotril for treating acute diarrhoea in children under five years of age.

\section{Search methods}

We searched the Cochrane Infectious Diseases Group Specialized Register; the Cochrane Central Register of Controlled Trials (CENTRAL, published in the Cochrane Library Issue 3, March 2019); MEDLINE; Embase; LILACS; ClinicalTrials.gov; and the World Health Organization International Clinical Trials Registry Platform (WHO ICTRP), up to 4 March 2019, for clinical trials regardless of publication language or status.

\section{Selection criteria}

Randomized controlled trials (RCTs) that compared racecadotril to placebo or no intervention in addition to standard care (oral rehydration therapy) in children under five with acute diarrhoea. The primary outcomes were failure of oral rehydration, duration of diarrhoea, and number of stools. The secondary outcomes were stool output, length of the hospital stay, and adverse events.

\section{Data collection and analysis}

Two review authors independently assessed trial eligibility, extracted the data and assessed risk of bias. We presented dichotomous data with risk ratios (RR) and continuous data with mean difference (MD) or standardized mean difference (SMD). Where appropriate, we combined trials with meta-analysis and used a random-effects model if there was significant heterogeneity $\left(I^{2} \geq 50 \%\right)$. We assessed the certainty of the evidence using the GRADE approach. 


\section{Main results}

Seven RCTs with a total of 1140 participants met the inclusion criteria. The trials were carried out on children aged three months to five years, in outpatient and inpatient facilities from France, Spain, Peru, India, Kenya, and Ecuador. The efficacy and safety of racecadotril were compared to placebo or no treatment. Racecadotril may reduce the risk of rehydration failure (RR $0.41,95 \% \mathrm{Cl} 0.13$ to $1.23 ; 2 \mathrm{RCTs}$, 192 participants; low-certainty evidence). Data on duration of diarrhoea, number of stools in the first 48 hours are insufficient to reach a conclusion; stool output in the first 48 hours appears to be lower in the two trials measuring this, although the data is not combinable. Length of hospital stay was similar in two studies measuring this, and overall there was no evidence that racecadotril increased overall rate of adverse events (RR 0.90, 95\% Cl 0.66 to 1.22; 5 RCTs, 688 participants; low-certainty evidence). Most adverse events in the racecadotril group were mild or moderate.

\section{Authors' conclusions}

Racecadotril seems to be a safe drug but has little benefit in improving acute diarrhoea in children under five years of age. Current evidence does not support routine use of racecadotril in management of acute diarrhoea in children under five outside of the context of placebo controlled RCTs.

18 December 2019

Up to date

All studies incorporated from most recent search

All studies identified during the most recent search (4 Mar, 2019) have been incorporated in the review, and no ongoing studies identified.

\section{PLAIN LANGUAGE SUMMARY}

\section{Racecadotril to treat children under five years of age with acute diarrhoea}

\section{What was the aim of this review?}

The aim of this Cochrane Review was to find out whether racecadotril works for children under five years of age with diarrhoea. Cochrane Review authors collected and analysed all relevant trials to answer this question and included seven trials in this review.

\section{Key messages}

Racecadotril may reduce the risk of rehydration failure. We are uncertain whether or not it influences number of bowel movements or duration of diarrhoea.

\section{What was studied in the review?}

Diarrhoea is a leading cause of death in children under five years old, especially in low-income countries. Children who have diarrhoea often suffer from frequent and watery bowel movements, which might cause excessive loss of fluid and electrolytes (dehydration). Fluid replacement is recommended to prevent and treat dehydration caused by diarrhoea. Racecadotril has been used in addition to fluid replacement for treating diarrhoea in children, as it reduces release of water and electrolytes into the digestive tract. The drug is supposed to improve the symptoms of diarrhoea (shorten duration of diarrhoea or reduce the stool frequency) as well as reduce the risk of rehydration failure. However, it is not clear if racecadotril really works for children with diarrhoea.

\section{What are the main results?}

The review authors searched for available trials and included seven trials. The trials were conducted in a total of 1140 children aged from 3 months to 5 years. Children who were given racecadotril were compared to a control group (children who, instead of racecadotril, received a placebo (a dummy drug that contains no racecadotril) or no drug). The review shows that when children with diarrhoea were given racecadotril, compared to placebo or no drug:

- racecadotril may reduce the risk of rehydration failure (low-certainty evidence);

- we are uncertain whether or not racecadotril shortens duration of diarrhoea (very low-certainty evidence);

- we are uncertain whether racecadotril influences the number of stools (very low-certainty evidence);

- racecadotril may reduce weight of stool output (low-certainty evidence);

- racecadotril may make little or no difference to length of hospital stay for inpatients (low-certainty evidence);

- racecadotril may make little or no difference to rates of side-effect events (low-certainty evidence)

\section{How up to date is this review?}

The review authors searched for trials published up to 4 March 2019. 
SUMMARY OF FINDINGS

Summary of findings for the main comparison. Summary of findings table 1

Racecadotril compared to placebo/no treatment for acute diarrhoea in children

Patient or population: acute diarrhoea in children

Setting: hospital and outpatients

Intervention: racecadotril

Comparison: placebo/no treatment

\begin{tabular}{|c|c|c|c|c|c|c|}
\hline \multirow[t]{2}{*}{ Outcomes } & \multicolumn{2}{|c|}{ Anticipated absolute effects ${ }^{\star}(95 \% \mathrm{Cl})$} & \multirow{2}{*}{$\begin{array}{l}\text { Relative ef- } \\
\text { fect } \\
(95 \% \mathrm{CI})\end{array}$} & \multirow{2}{*}{$\begin{array}{l}\text { Number of } \\
\text { participants } \\
\text { (trials) }\end{array}$} & \multirow{2}{*}{$\begin{array}{l}\text { Certainty of the evi- } \\
\text { dence } \\
\text { (GRADE) }\end{array}$} & \multirow[t]{2}{*}{ Comments } \\
\hline & $\begin{array}{l}\text { Risk with place- } \\
\text { bo/no treatment }\end{array}$ & $\begin{array}{l}\text { Risk with } \\
\text { racecadotril }\end{array}$ & & & & \\
\hline $\begin{array}{l}\text { Failure of rehydra- } \\
\text { tion }\end{array}$ & 106 per 1000 & $\begin{array}{l}44 \text { per } 1000 \\
(14 \text { to } 131)\end{array}$ & $\begin{array}{l}\text { RR } 0.41 \\
\text { (0.13 to } 1.23 \text { ) }\end{array}$ & $\begin{array}{l}192 \\
(2 \mathrm{RCTs})\end{array}$ & $\begin{array}{l}\oplus \oplus \ominus \ominus \\
\text { LOWa,b } \\
\text { Due to risk of bias and } \\
\text { imprecision }\end{array}$ & $\begin{array}{l}\text { Racecadotril may reduce the risk of } \\
\text { failure of rehydration }\end{array}$ \\
\hline $\begin{array}{l}\text { Duration of diar- } \\
\text { rhoea }\end{array}$ & $\begin{array}{l}\text { Not pooled: mean } \\
\text { and median were in- } \\
\text { consistently report- } \\
\text { ed }\end{array}$ & $\begin{array}{l}2 \text { trials concluded } \\
\text { that racecadotril } \\
\text { might shorten du- } \\
\text { ration of diarrhoea } \\
\text { while } 3 \text { with lower } \\
\text { overall risk of bias re- } \\
\text { ported no difference } \\
\text { between two groups } \\
\text { on this outcome }\end{array}$ & - & $\begin{array}{l}867 \\
\text { (5 RCTs) }\end{array}$ & $\begin{array}{l}\oplus \ominus \ominus \ominus \\
\text { VERY LOWc,d } \\
\text { Due to risk of bias and } \\
\text { inconsistency }\end{array}$ & $\begin{array}{l}\text { We are uncertain whether or not } \\
\text { racecadotril shortens duration of di- } \\
\text { arrhoea. }\end{array}$ \\
\hline $\begin{array}{l}\text { Number of stools: } \\
\text { measured in the } \\
\text { first } 24 \text { hours af- } \\
\text { ter introduction of } \\
\text { racecadotril }\end{array}$ & 4.8 stools/person & $\begin{array}{l}\text { In the racecadrotril } \\
\text { group, patients on } \\
\text { average had } 0.24 \\
\text { stools less than the } \\
\text { control group ( } 95 \% \\
\mathrm{Cl}-0.90 \text { to } 0.43 \text { ) }\end{array}$ & & $\begin{array}{l}258 \\
(2 \mathrm{RCTS})\end{array}$ & $\begin{array}{l}\oplus \ominus \ominus \ominus \\
\text { VERY LOWe,f } \\
\text { Due to risk of bias and } \\
\text { inconsistency }\end{array}$ & $\begin{array}{l}\text { We are uncertain whether } \\
\text { racecadotril influences the number } \\
\text { of stools }\end{array}$ \\
\hline $\begin{array}{l}\text { Stool output: } \\
\text { measured in the } \\
\text { first } 48 \text { hours af- } \\
\text { ter introduction of } \\
\text { racecadotril }\end{array}$ & $\begin{array}{l}\text { The mean stool out- } \\
\text { put was } 331 \mathrm{~g} / \mathrm{kg}\end{array}$ & $\begin{array}{l}\text { The mean stool } \\
\text { output in the } \\
\text { racecadotril group } \\
\text { was } 25.35 \mathrm{~g} / \mathrm{kg} \text { lower }\end{array}$ & - & $\begin{array}{l}301 \\
(2 \mathrm{RCTS})\end{array}$ & $\begin{array}{l}\oplus \oplus \ominus \ominus \\
\text { LOW g,h } \\
\text { Due to risk of bias and } \\
\text { imprecision }\end{array}$ & $\begin{array}{l}\text { Racecadotril may reduce stool out- } \\
\text { put; it was estimated using a } \\
\text { standardised mean difference of } \\
-0.65(-0.88 \text { to }-0.41)\end{array}$ \\
\hline
\end{tabular}




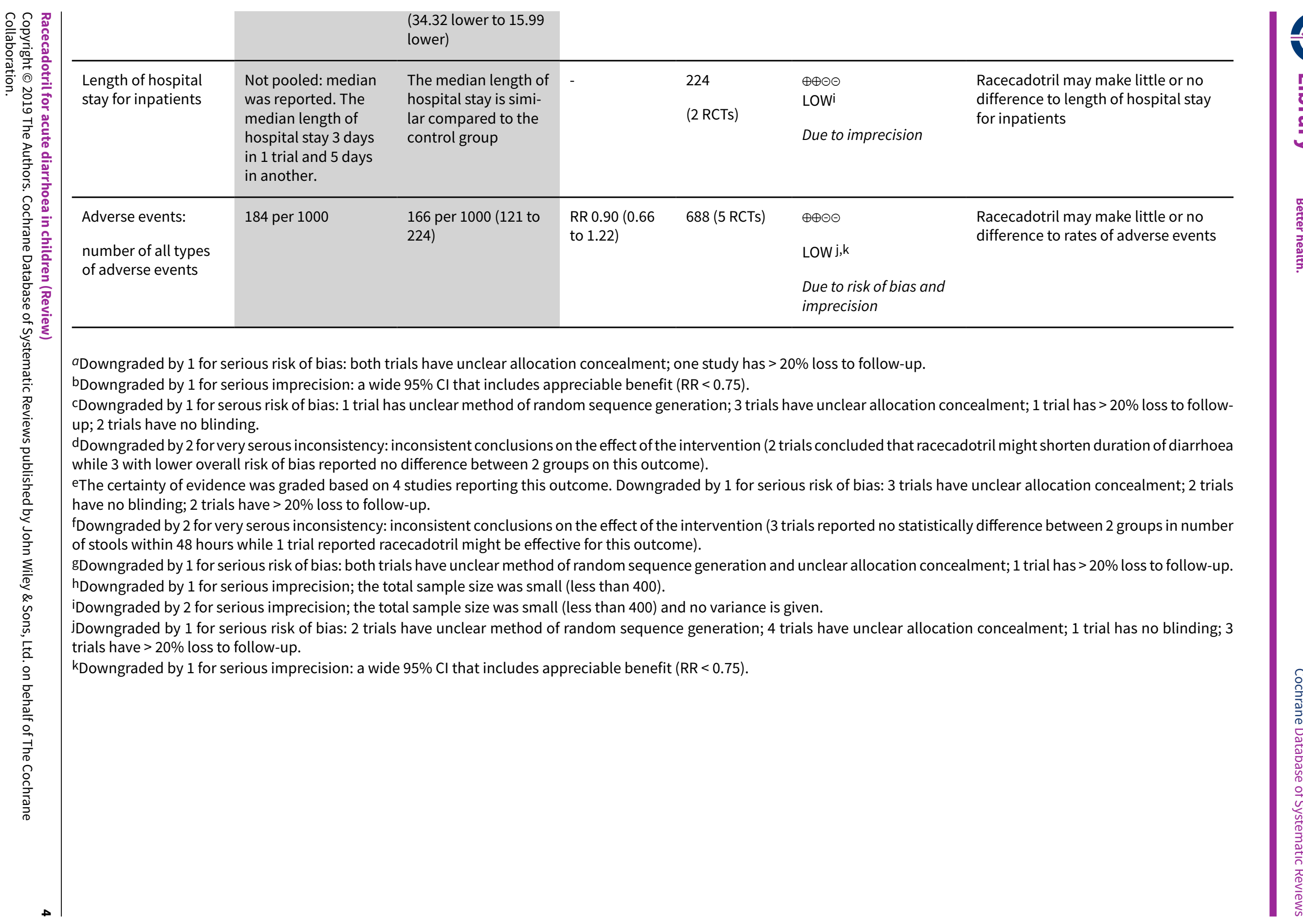




\section{B A C K G R O U N D}

\section{Description of the condition}

Diarrhoea is defined as the passage of three or more loose or liquid stools per day (WHO 2017). Acute diarrhoea lasts usually several hours or days, while persistent diarrhoea has a duration of 14 days or longer. Acute diarrhoea remains a leading cause of death for children under five years of age. Each year, an estimated 1.7 billion cases of acute diarrhoea occur worldwide among children, leading to around 525,000 deaths (WHO 2017). Acute diarrhoea is a common symptom of gastrointestinal infections mostly caused by a wide range of pathogens, including bacteria, viruses, and protozoa. However, just a handful of organisms are responsible for most acute cases of childhood diarrhoea, with rotavirus being the leading cause of acute diarrhoea among children under five (WHO 1999; WHO 2008). Most deaths from acute diarrhoea are caused by excessive fluid and electrolyte losses (Tormo 2008), and most are therefore avoidable provided losses are replaced promptly by rehydration. Oral rehydration therapy has been recommended as the essential treatment for acute diarrhoea in children (NICE 2009; UNICEF/WHO 2004). A network meta-analysis reported that 27 different types of treatments or treatment combinations for children with acute diarrhoea were studied in clinical trials; and it concluded that zinc, Saccharomyces boulardii combined with zinc, and smectite combined with zinc showed the best combination of evidence quality and magnitude of effect, especially in low- and middle-income countries (Florez 2018).

\section{Description of the intervention}

Racecadotril is an anti-secretory drug that exerts its anti-diarrhoeal effects by rapidly hydrolyzing to the active metabolite thiorphan, which is a powerful and selective inhibitor of the enzyme enkephalinase (Schwartz 2000). It prevents the degradation of endogenous enkephalins and thus reduces hypersecretion of water and electrolytes into the intestinal lumen without interfering with motility (Primi 1999). Unlike loperamide, racecadotril does not act on $\mu$-opioid receptors and therefore does not prolong intestinal transit, nor does it encourage bacterial growth in the small intestine (Maldonado 2006). Also, unlike the antisecretory drug bismuth salicylate, racecadotril is not associated with a risk of developing Reye's syndrome (Abramson 1993).

The World Health Organization (WHO) has recommended oral rehydration solution and zinc for the routine treatment of acute diarrhoea in children (WHO 2005). Oral rehydration therapy does not, however, provide relief of diarrhoeal symptoms, which can be distressing for both children and their caregivers (Szajewska 2007). Racecadotril has been used for acute diarrhoea in children as an adjunct to oral rehydration therapy, especially in Europe, South America and several Asian countries (Bioprojet Pharma 2007). It might help improve the success of rehydration by reducing fluid loss and provide relief on the diarrhoeal symptoms by reducing stool frequency or shortening the duration of diarrhoea, or both. A meta-analysis of randomized controlled studies in adults showed that racecadotril can shorten diarrhoea duration and reduce number of stools, compared to placebo (Coffin 2014). According to published studies, it also has good tolerability both in children and adults, with adverse effects similar to placebo groups (Alam 2003; Cézard 2001). A cost-utility analysis from the perspective of a UK payer found racecadotril as adjuvant therapy was more effective and less costly compared to oral rehydration therapy alone for children's diarrhoea (Rautenberg 2012).

\section{Why it is important to do this review}

Although racecadotril has been used in many countries, WHO and National Institute for Health and Clinical Excellence (NICE) guidelines have not recommended use of any antidiarrhoeal drugs in children under five (NICE 2009; WHO 2017). The ESPGHAN evidence-based guideline, Guarino 2014, mentioned that racecadotril may be considered in the management of acute diarrhoea in children but well-designed prospective studies should be carried out in outpatient children, since outpatients account for the majority of rotavirus-associated cases of diarrhoea in children (Parashar 2003). A systematic review covering a small number of earlier published trials found that racecadotril was effective in reducing weight and frequency of stool output as well as shortening the duration of diarrhoea in children (Szajewska 2007). However, stool output weight, as the primary outcome, has limited practical value and tends to be influenced by factors such as food intake and to be contaminated by urine. Two systematic reviews or meta-analyses concluded that racecadotril was effective in children with acute diarrhoea; risk of bias was not assessed for included trials in those reviews, however (Eberlin 2018; Lehert 2011). In addition, one of the main purposes of using racecadotril is to prompt correction of water-electrolyte disturbances, and thus outcomes for evaluating the success of rehydration should also be included. Previous reviews did not include this outcome when evaluating the efficacy of racecadotril (Gordon 2016; Lehert 2011; Szajewska 2007). Although several systematic reviews have been conducted in order to assess the efficacy of racecadotril for children with acute diarrhoea, the benefit of using racecadotril is still controversial as newly published trials have inconsistent conclusions on its efficacy (García 2016; Gharial 2017; Kang 2016a; Kang 2016b; Sreenivas 2017). An updated systematic review that carefully assesses risk of bias of available trials and addresses outcomes both on symptomatic relief and success of rehydration was needed.

\section{OB JECTIVES}

To assess the efficacy and safety of racecadotril for treating acute diarrhoea in children under five years of age.

\section{METHODS}

\section{Criteria for considering studies for this review}

\section{Types of studies}

Randomized controlled trials (RCTs).

\section{Types of participants}

Children less than five years old with uncomplicated acute diarrhoea, defined as passing loose or watery stools at least three times in a 24-hour period and lasting less than seven days.

\section{Types of interventions}

\section{Intervention}

Orally administered racecadotril irrespective of dose, duration, and interval of administration. 


\section{Control}

Placebo, or no treatment.

Oral rehydration therapy as the standard care should be given to both intervention and control groups. We also included trials in which both groups received zinc as an adjunct to oral rehydration therapy, as it is recommended by the WHO. (UNICEF/WHO 2004)

\section{Types of outcome measures}

\section{Primary outcomes}

- Failure of oral rehydration, defined as any of the following: worsening or no improvement of dehydration; recurring dehydration; need for unscheduled intravenous fluid infusion; participants initially without dehydration subsequently developing dehydration; or need for hospital admission in outpatients.

- Duration of diarrhoea, defined as the time period in days from randomization or start of treatment to the resolution of diarrhoea.

- Number of stools, defined as the number of stools or bowel movements within 48 hours after administration of interventions.

\section{Secondary outcomes}

- Stool output: the accumulated weight of stool output within 48 hours, measured by using diapers or others ways.

- Length of hospital stay for inpatients: the time period in days from randomization or the start of treatment to hospital discharge for hospitalized patients.

- Adverse events: number of all types of adverse events.

\section{Search methods for identification of studies}

We attempted to find all relevant trials regardless of language or publication status (published, unpublished, in press, and in progress).

\section{Electronic searches}

We searched the following databases: the Cochrane Infectious Diseases Group Specialized Register; the Cochrane Central Register of Controlled Trials (CENTRAL, published in the Cochrane Library issue 3, March 2019); MEDLINE (via OVID, 1966 to 4 March 2019); Embase (via OVID, 1980 to 4 March 2019); and LILACS (1982 to 4 March 2019), using the search terms detailed in Appendix 1. We also searched Clinicaltrials.gov and the search portal of the World Health Organization International Clinical Trials Registry Platform (WHO ICTRP), to identify ongoing or unpublished trials, using "diarrh"”, "racecadotril" and "child"” as search terms. All the search work was up to 4 March 2019.

\section{Searching other resources}

We reviewed the citations of existing reviews and clinical trials obtained by the above methods. We also contacted individual researchers and pharmaceutical companies for data of unpublished trials.

\section{Data collection and analysis}

\section{Selection of studies}

Two review authors ( $Y L$ and $L Z$ ) independently screened the titles and abstracts of all studies identified by the search strategy and obtained the full articles for all potentially relevant trials. We independently assessed the full text using an eligibility form based on the inclusion criteria. We resolved disagreements by discussion until consensus was achieved. We scrutinized each of the articles to ensure that each trial was included only once. We documented the reasons for excluding trials in the Characteristics of excluded studies table. We constructed a PRISMA diagram to illustrate the study selection process.

\section{Data extraction and management}

Two review authors (YL and LZ) independently extracted the data using a pre-designed data collection form. The extracted items included: 1) authors; 2) year of publication; 3) the country where the trial was conducted; 4) number of participants randomized into each group; 5) inclusion and exclusion criteria; 6 ) interventions in both groups; 7) dose and duration of racecadotril; 8) outcomes; 9) source of funding. For each treatment arm, we extracted the number of participants randomized to each group and the number of analysed participants for each outcome. For dichotomous outcomes, we extracted the number of participants experiencing the event in each group of the trial; for continuous data, we extracted means and standard deviations (median and interquartile for skewed data). Studies that were published in languages other than English were translated with the help of Cochrane Infectious Diseases Group.

\section{Assessment of risk of bias in included studies}

Two review authors (YL and LZ) independently assessed the risk of bias using the Cochrane 'Risk of bias' tool, which addresses six specific domains: sequence generation, allocation concealment, blinding, incomplete outcome data, selective outcome reporting, and other bias (Higgins 2011). We categorized the judgements as low, high or unclear risk of bias, and documented reasons for each judgement. We resolved disagreements by discussion or consulting methodologists from the Chinese Cochrane Center. We created plots of risk of bias assessment in Review Manager 5 (RevMan 5) (Review Manager 5). We contacted authors of included trials for additional information if needed for risk of bias assessment.

\section{Measures of treatment effect}

We used risk ratio for dichotomous data and mean difference (standardized mean difference if the outcome was reported on different scales) for continuous data, presenting with $95 \%$ confidence intervals.

\section{Dealing with missing data}

We attempted to contact the trial authors when data were insufficient or missing. We noted proportions of participants for whom we could obtain no outcome data, and reported them in a 'Risk of bias' table. We dealt with missing data at individual study and outcome level. We checked the number of children lost to follow-up and the reasons for missing data in each group. If, in accordance with the guidance in Guyatt 2011b, the proportion was less than $20 \%$ and meanwhile the reasons and numbers of missing were balanced in the two groups, we graded the risk of attrition bias 
as low; otherwise, we graded it as high. We performed sensitivity analyses based on participants originally assigned to two groups or reported results from intention-to-treat (ITT) analyses in the original clinical trials if no meta-analysis was conducted.

\section{Assessment of heterogeneity}

We judged clinical heterogeneity based on our knowledge at patient, intervention, control and outcome level. We used the $\mathrm{I}^{2}$ statistic to check statistical heterogeneity, considering an $\mathrm{I}^{2}$ value of $50 \%$ or greater to denote significant heterogeneity. We used a fixed-effect model to synthesize data when heterogeneity was not significant $\left(I^{2}<50 \%\right)$ and a random-effects model when heterogeneity was significant $\left(I^{2} \geq 50 \%\right)$.

\section{Assessment of reporting biases}

We planned to examine publication bias using a funnel plot, and to use a regression approach to assess funnel plot asymmetry if more than nine trials reported the same outcome (Egger 1997). However the number of included trials failed to meet the requirements, so we did not conduct analysis of reporting bias.

\section{Data synthesis}

We conducted meta-analyses using Review Manager 5 (RevMan 5), and present the results with 95\% confidence intervals (CI) (Deeks 2011). For failure of rehydration and adverse effects, we calculated the pooled estimate of the risk ratio (RR) between two groups. For duration of diarrhoea, number of stools, stool output, and length of hospital stay, we planned to pool the results by calculating the mean difference or standardized mean difference. If included trials reported results using median instead of means, this might indicate that the data were skewed so we did not combine those results in meta-analysis (Deeks 2011). We used either a fixed-effect or random-effects model according to the heterogeneity in outcomes across trials assessed by the $I^{2}$ statistic test.

\section{Subgroup analysis and investigation of heterogeneity}

We expected to conduct subgroup analysis on inpatient versus outpatient groups, different disease severity groups, rotavirus versus non-rotavirus groups and different dosage of racecadotril.

\section{Sensitivity analysis}

We conducted sensitivity analyses by limiting the analyses to those with lower overall risk of bias, especially with adequate randomization, allocation concealment, and blinding. We also performed sensitivity analyses on binary outcomes based on the number of participants originally randomized into two groups or reported results of ITT analyses from original clinical trials for both continuous and dichotomous outcomes for sensitivity purposes.

\section{Assessment of the certainty of the evidence}

We assessed the certainty of the evidence using the GRADE approach and used the GRADEpro Guideline Development Tool (GDT) to create the 'Summary of findings' tables (GRADEpro GDT). The certainty rating of the studies has four levels: high, moderate, low, and very low. RCTs are initially categorized as high certainty but can be downgraded after assessment of five aspects: risk of bias, consistency, directness, imprecision, and publication bias (Guyatt 2011a). In the GRADE system, high-certainty evidence denotes that further research is unlikely to change our confidence in the estimate of effect; moderate-certainty evidence denotes that further research is likely to have an important impact on confidence in the estimate of effect and may change the estimate; low-certainty evidence denotes that further research is very likely to have an important impact on confidence in the estimate of effect and is likely to change the estimate; very low certainty evidence denotes a serious lack of confidence in the effect estimate (Schünemann 2011). For outcomes for which we could not obtain a single pooled estimate, we assessed the certainty of evidence based on all trials that reported the same outcome and presented estimates with narrative description in the 'Summary of findings' table (Murad 2017).

\section{RES U L T S}

\section{Description of studies}

\section{Results of the search}

We identified 213 citations by initial searching of databases and 9 records from clinical trial registry platforms. During study selection we encountered three non-English articles and obtained help from the Cochrane Infectious Diseases Group (CIDG) with translating them into English (Calatayud 2009; Cojocaru 2002; García 2016). After selecting according to inclusion criteria, we included seven RCTs, involving 1140 participants (Cézard 2001; García 2016; Gharial 2017; [Kang 2016a; Kang 2016b]; Salazar-Lindo 2000; Santos 2009; Sreenivas 2017). See Figure 1 for a flow diagram of the selection process. 
Figure 1. Study flow diagram.

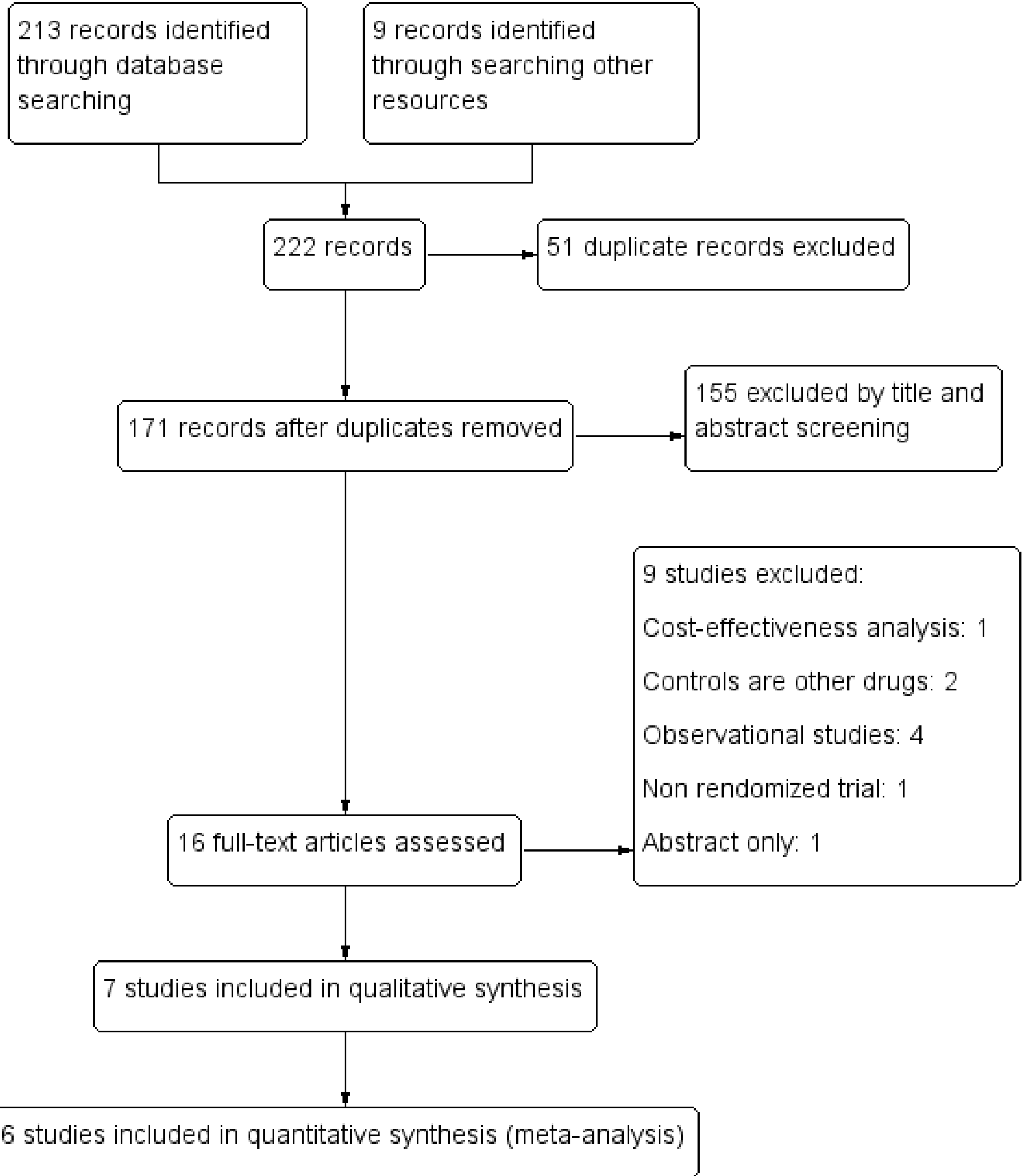




\section{Included studies}

See: Characteristics of included studies

\section{Setting}

Two trials were conducted in India ([Kang 2016a; Kang 2016b]; Sreenivas 2017); the rest were conducted in France (Cézard 2001), Spain (Santos 2009), Peru (Salazar-Lindo 2000), Kenya (Gharial 2017), and Ecuador (García 2016).

\section{Participants}

Participants were aged from three months to 5 years. All trials excluded patients who received antibiotics or other anti-diarrhoeal drugs during this episode of diarrhoea. Two did not exclude participants with comorbid diseases or conditions like HIV and severe malnutrition (Gharial 2017; Santos 2009). Salazar-Lindo 2000 studied only boys to minimize the contamination of stool by urine in assessment of stool output. Gharial 2017 and [Kang 2016a; Kang 2016b] graded the severity of diarrhoea with the Vesikari score (Lewis 2011); and Gharial 2017 included participants with a score greater than 11 (severe) only. Two trials included outpatients only (García 2016; Santos 2009); while four included inpatients only (Cézard 2001; Gharial 2017; Salazar-Lindo 2000; Sreenivas 2017). One trial included both inpatients and outpatients but reported their results separately (Kang 2016a; Kang 2016b). Sreenivas 2017 included paediatric ward inpatients but children with severe diarrhoea were excluded.

\section{Interventions}

In Santos 2009 and García 2016, 10 mg of racecadotril was given every 8 hours for children weighing less than $9 \mathrm{~kg}, 20 \mathrm{mg}$ every 8 hours for children weighing $9 \mathrm{~kg}$ to $13 \mathrm{~kg}$, and $30 \mathrm{mg}$ every 8 hours for those weighing more than $13 \mathrm{~kg}$. In Gharial 2017, racecadotril was administered at $10 \mathrm{mg}$ per dose for children below 12 months of age and $30 \mathrm{mg}$ for those over 12 months of age. In the other four trials, racecadotril was given three times daily at a dose of 1.5 mg/kg (Cézard 2001; [Kang 2016a; Kang 2016b]; Salazar-Lindo 2000; Sreenivas 2017).

\section{Comparison}

Five trials used placebo as control compared to racecadotril (Cézard 2001; García 2016; Gharial 2017; [Kang 2016a; Kang 2016b]; SalazarLindo 2000), while in the other two, racecadotril was compared to no treatment in addition to standard therapy (Santos 2009; Sreenivas 2017).

\section{Outcomes}

Two trials reported the primary outcome 'failure of rehydration' (García 2016; Sreenivas 2017). All except one -García 2016- reported the outcome 'duration of diarrhoea'. Two trials reported the number of outpatients' stools during the first and second day after treatment (García 2016; Santos 2009); and two reported the number of stools within 48 hours in inpatients (Gharial 2017; Sreenivas 2017). Three trials reported the weight of stool output (Cézard 2001; Kang 2016a; Salazar-Lindo 2000). Two reported the outcome 'length of hospital stay' (Gharial 2017; Kang 2016a). All except one reported adverse events (Kang 2016a; Kang 2016b).

\section{Funding}

Three trials were supported by the pharmaceutical industry (Gharial 2017; Salazar-Lindo 2000; Santos 2009). García 2016 did not clearly report source of funding. One failed to report the source of funding but several authors are from pharmaceutical industry (Cézard 2001). Kang 2016a and Kang 2016b received funding from a governmental organization (Swedish International Development Agency) and Sreenivas 2017 did not receive any funding for conducting the trial.

\section{Excluded studies}

See: Characteristics of excluded studies

\section{Risk of bias in included studies}

See Figure 2 and Figure 3 for a summary of risk of bias assessment. We emailed the authors of included trials for further information regarding risk of bias but only one replied (Gharial 2017). We were not able to contact authors from two trials as the email addresses listed in the articles are no longer valid (Cézard 2001; Salazar-Lindo 2000). 
Figure 2. 'Risk of bias' graph: review authors' judgements about each 'Risk of bias' item presented as percentages across all included trials.

Random sequence generation (selection bias)

Allocation concealment (selection bias)

Blinding of participants and personnel (performance bias)

Blinding of outcome assessment (detection bias)

Incomplete outcome data (attrition bias)

Selective reporting (reporting bias)

Other bias

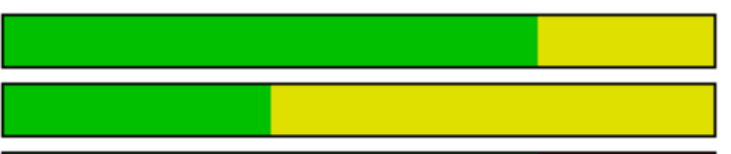

L

L

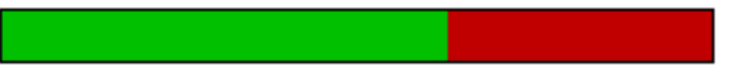

\footnotetext{
$$
\text { L }
$$
}
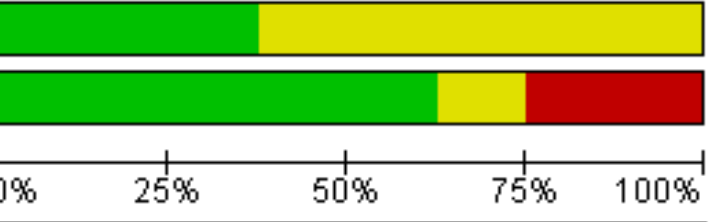

Low risk of bias

Unclear risk of bias

High risk of bias 
Figure 3. 'Risk of bias' summary: review authors' judgements about each 'Risk of bias' item for each included trial.

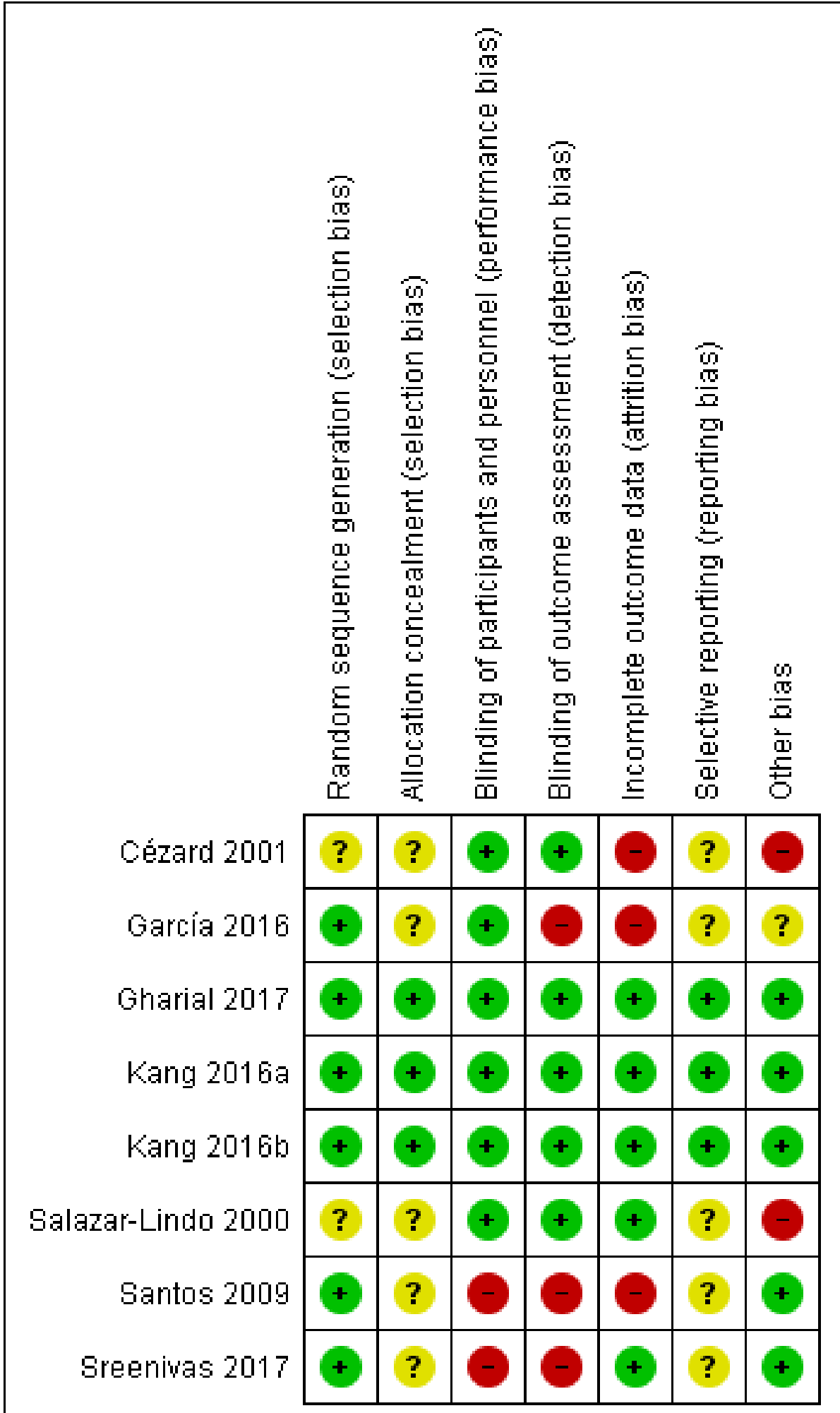

\section{Allocation}

Five trials were at high risk of selection bias: two failed to report how the random sequence was created (Cézard 2001; Salazar-Lindo 2000); and five did not report if allocation concealment was conducted (Cézard 2001; García 2016; SalazarLindo 2000; Santos 2009; Sreenivas 2017). Two trials reported that allocation concealment was achieved by sealed envelopes with randomization codes given directly to the hospital pharmacy ([Kang 2016a; Kang 2016b]; Gharial 2017). 


\section{Blinding}

Two trials were at high risk of performance bias and detection bias for no blinding (Santos 2009; Sreenivas 2017). Five were reported as double-blinded placebo-controlled trials (Cézard 2001; García 2016; Gharial 2017; [Kang 2016a; Kang 2016b]; Salazar-Lindo 2000).

\section{Incomplete outcome data}

Three trials were at high risk of attrition bias, two due to high loss to follow-up (> 20\%) (Cézard 2001; Santos 2009) and one due to imbalance in loss to follow-up (García 2016). Four trials were at low risk of attrition bias (Gharial 2017; [Kang 2016a; Kang 2016b]; Salazar-Lindo 2000; Sreenivas 2017).

\section{Selective reporting}

Five trials had unclear risk of reporting bias as it was not reported if their research protocols were registered or accessible (Cézard 2001; García 2016; Salazar-Lindo 2000; Santos 2009; Sreenivas 2017). It was unknown whether all the pre-designed outcomes in those trials had been reported. Two trials have research protocols registered on clinical trial registration platforms and reported all pre-designed outcomes (Gharial 2017; [Kang 2016a; Kang 2016b]).

\section{Other potential sources of bias}

Three trials were supported by the pharmaceutical industry (Gharial 2017; Salazar-Lindo 2000; Santos 2009), and one failed to report the role of the pharmaceutical company in the trial, leading to high risk of bias for potential conflict of interest (SalazarLindo 2000). Santos 2009 clearly reported that the pharmaceutical company was not involved in data collection, analysis and result interpretation; Gharial 2017 received part of its funding from the pharmaceutical industry but, as the conclusion did not favour the company, there was low risk of bias caused by conflict of interest. One trial failed to report source of funding, but some authors were from the pharmaceutical industry, causing potentially high risk of bias (Cézard 2001).

\section{Effects of interventions}

See: Summary of findings for the main comparison Summary of findings table 1

\section{Failure of rehydration}

Two trials reported outcomes that can be categorized into failure of rehydration (García 2016; Sreenivas 2017). Participants in these two trials all have mild to moderate diarrhoea, even though Sreenivas 2017 was conducted in an inpatient setting and García 2016 was conducted in outpatients from the emergency room. One (113 participants) reported that three children from the racecadotril group and seven from the placebo group received intravenous fluid therapy due to worsening of dehydration (Sreenivas 2017). The other trial (79 participants) found that one child from the racecadotril group and seven from the placebo group were hospitalized after treatment in the emergency room (García 2016). The pooled analysis showed that there was no significant difference between racecadotril and control group on the rate of rehydration failure (RR $0.41,95 \% \mathrm{Cl} 0.13$ to $1.23, \mathrm{I}^{2}=0 \%$; 2 trials, 192 participants; Analysis 1.1; Figure 4). The sensitivity analysis based on the number of participants originally randomized in two groups does not change the significance of the result.

\section{Figure 4. Comparison 1 Racecadotril versus placebo/no treatment, Outcome 1.1 Failure of rehydration.}

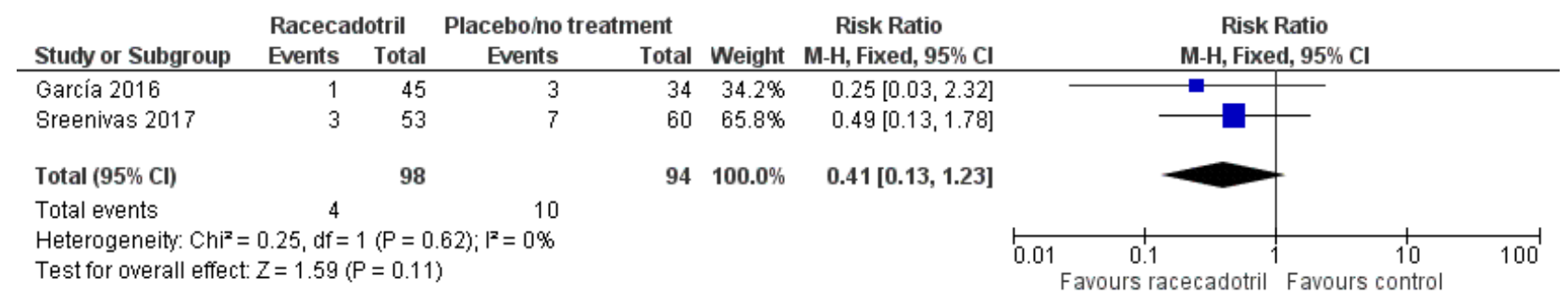

\section{Duration of diarrhoea}

Five trials (867 participants) reported the average duration of diarrhoea in two groups. Three trials included only inpatients (Gharial 2017; Salazar-Lindo 2000; Sreenivas 2017); one included only outpatients (Santos 2009); and one was conducted on both inpatients and outpatients (Kang 2016a; Kang 2016b). No pooled analysis was conducted as the outcome was reported inconsistently with mean or median (Table 1). Overall, three trials (619 participants) with lower risk of bias reported no significant difference on duration of diarrhoea between two groups (Gharial 2017; [Kang 2016a; Kang 2016b]; Santos 2009); while the other two (248 participants) showed duration of diarrhoea was shorter in those receiving racecadotril (Salazar-Lindo 2000; Sreenivas 2017).

\section{Number of stools}

Four trials (491 participants) reported number of stools in two groups. No pooled analysis was conducted across all four trials as the outcomes were measured with different time period and were reported inconsistently with mean or median (García 2016; Gharial 2017; Santos 2009; Sreenivas 2017). Two trials reported the daily mean number of stools and the pooled analysis shows that the daily number of stools was not significantly different between two groups, both at 24 hours (MD $-0.24,95 \% \mathrm{Cl}-0.90$ to 0.43 , $\mathrm{I}^{2}=36 \%$; 2 trials, 258 outpatients; Analysis 1.2; Figure 5) and 48 hours after treatment (MD $-0.80,95 \% \mathrm{Cl}-1.87$ to $0.27, \mathrm{I}^{2}=67 \% ; 2$ trials, 258 outpatients; Analysis 1.3; Figure 6) (García 2016; Santos 2009). Santos 2009 compared the number of stools at different time points according to microbiological results (bacterial and viral) of the stools cultures and found no significant difference between groups at any time of the visits. The trial also conducted a Poisson linear regression which showed a rapid decline in the number of stools in both groups without any statistically significant difference by 48 hours after the beginning of therapy. Similar results were obtained in both ITT and per protocol analyses. 
Figure 5. Forest plot of comparison: 1 Racecadotril versus placebo/no treatment, outcome: 1.2 Number of stools within 24 hours.

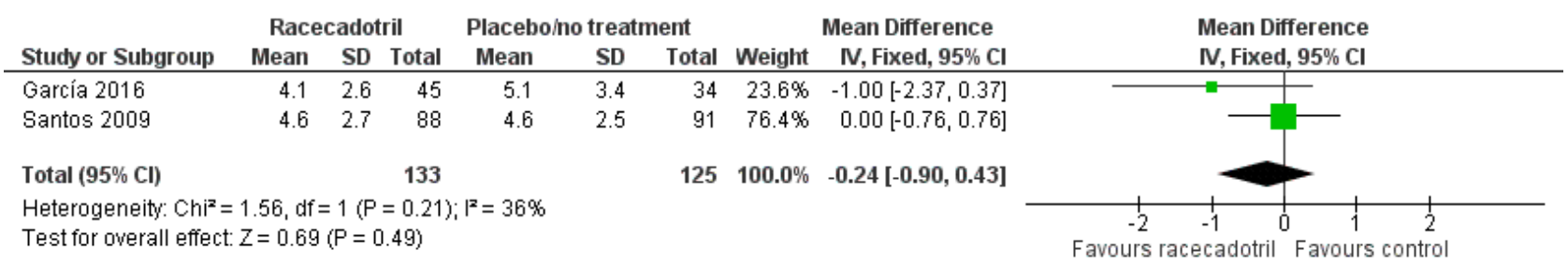

Figure 6. Forest plot of comparison: 1 Racecadotril versus placebo/no treatment, outcome: 1.3 Number of stools between 24 to 48 hours.

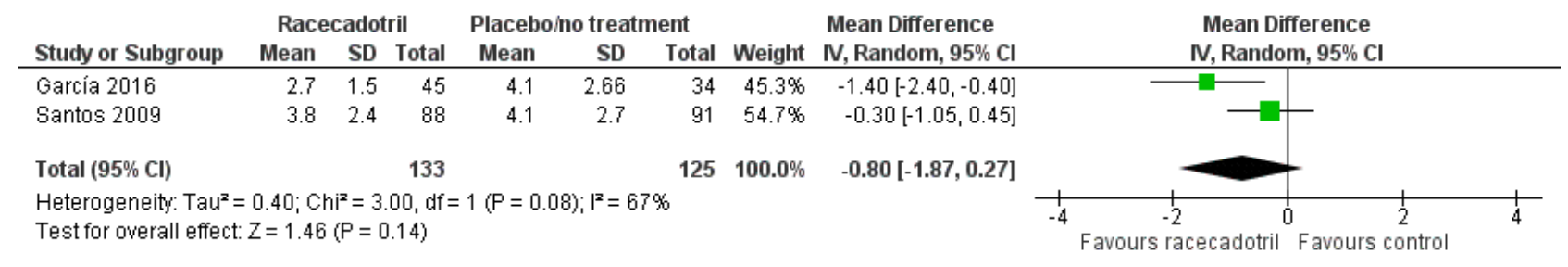

Gharial 2017 (120 inpatients) reported the median number of stools in the first 48 hours after introduction of racecadotril or placebo and it was five (IQR 3 to 7 ) in the racecadotril group and five (IQR 2.5 to $7.5)$ in the placebo group, and the difference was not significant $(P$ $=0.63$ ). However another trial (113 inpatients), with higher overall risk of bias, reported the mean number of stools within 48 hours was $10.5 \pm 3.2$ (SD) in racecadotril group and $15.9 \pm 4.6$ (SD) in the control group and the difference was significant $(P<0.001)$ (Sreenivas 2017).

\section{Stool output}

Two trials reported the stool output within 48 hours after treatment (Cézard 2001; Salazar-Lindo 2000).The pooled estimates showed that stool output was significantly lower in the racecadotril group than in the placebo group (SMD $-0.65,95 \% \mathrm{Cl}-0.88$ to $-0.41, \mathrm{I}^{2}=$ $0 \% ; 2$ trials, 301 inpatients; Analysis 1.5; Figure 7).

\section{Figure 7. Comparison 1 Racecadotril versus placebo/no treatment, Outcome 1.5 Stool output within 48 hours.}

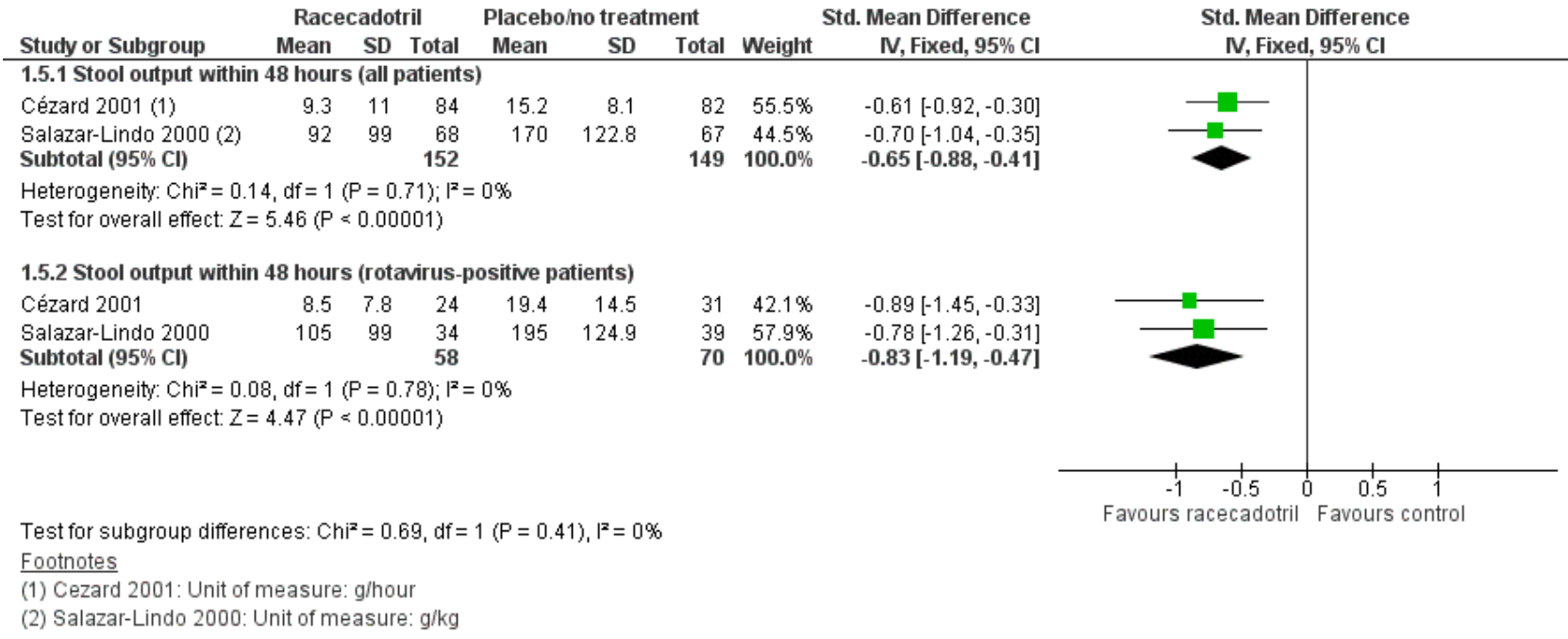

The subgroup analysis from data of rotavirus-positive children showed that the stool output was also significantly lower in the racecadotril group than in the placebo group (SMD $-0.83,95 \% \mathrm{Cl}$ -1.19 to $-0.47, \mathrm{I}^{2}=0 \%, 2$ trials, 128 inpatients; Analysis 1.5 ). One trial also reported that weight of stool output within 24 hours after drug treatment was significantly lower in the racecadotril group compared to placebo $(\mathrm{MD}=-5.50,95 \% \mathrm{Cl}-7.71$ to -3.29 ; 1 trial, 167 inpatients; Analysis 1.4; Figure 8). Stool output in the racecadotril group was significantly lower both in ITT $(P=0.025)$ and per protocol analysis $(P=0.015)$ (Cézard 2001). 
Figure 8. Comparison 1 Racecadotril versus placebo/no treatment, Outcome 1.4 Stool output within 24 hours.

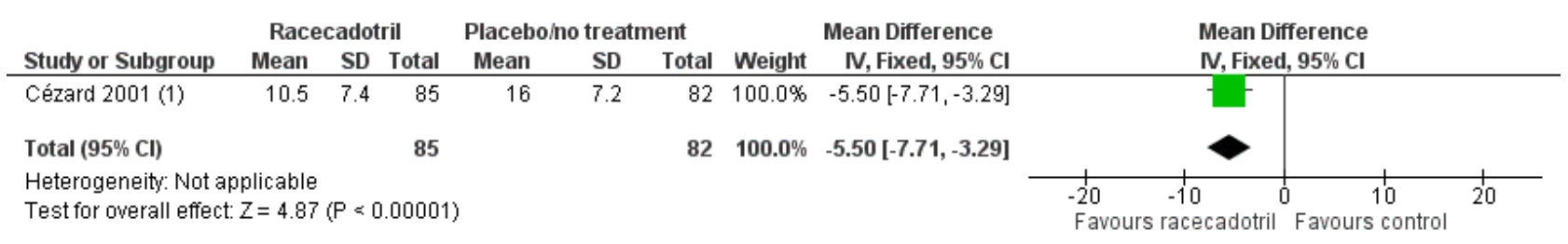

$\underline{\text { Footnotes }}$

(1) Cezard 2001: Unit of measure: g/hour

\section{Length of hospital stay for inpatients}

Two trials (244 participants) reported the median length of hospital stay in racecadotril and placebo group. Kang 2016a reported that length of hospital stay was three (IQR 2.4) days in both groups ( $\mathrm{P}=$ 0.96). Gharial 2017 also found no significant difference between two groups and the duration was 4 (IQR 1.5 to 6 ) days in the racecadotril group and 4.5 (1.8 to 6.3$)$ days in the placebo group $(P=0.71)$.

\section{Adverse effects}

Five trials (688 participants) reported the overall incidence of adverse events in two groups (Cézard 2001; García 2016; Gharial 2017; Salazar-Lindo 2000; Santos 2009). The pooled overall rate of adverse events was $17.4 \%$ in the racecadotril group and $18.4 \%$ in the control group (RR $0.90,95 \% \mathrm{Cl} 0.66$ to $1.22, \mathrm{I}^{2}=0 \%$; 5 trials, 688 participants; Analysis 1.6; Figure 9), showing no significant difference between two groups. The sensitivity analysis based on the number of participants originally randomized in two groups does not change the significance of the result.

Figure 9. Comparison 1 Racecadotril versus placebo/no treatment, Outcome 1.6 Adverse events.

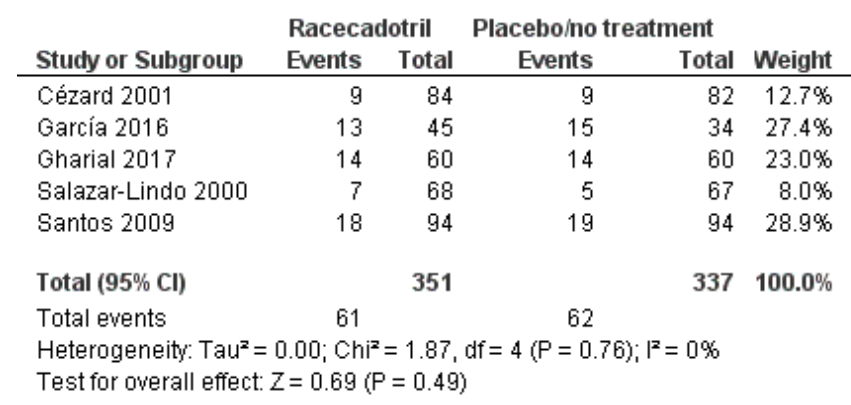

Risk Ratio

Risk Ratio

, Random, 95\% Cl M-H, Random, 95\% Cl

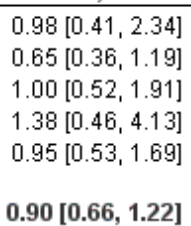

$\longrightarrow$

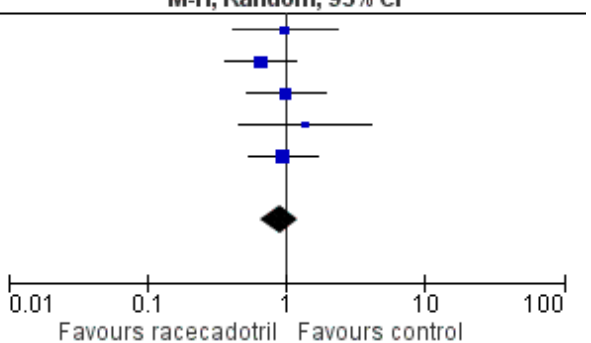

The commonly reported adverse events were urticaria and vomiting, but the latter may be related to the underlying diarrhoea aetiology. Santos 2009 reported three serious adverse effects. One child in the racecadotril group had an elevation in transaminases (ALT, $957 \mathrm{UI} / \mathrm{L}$; AST, $1357 \mathrm{UI} / \mathrm{L}$ ) causing one week of hospitalization, and the transaminases became normalized 3 months later. However, the causality is not clear as a viral infection was suspected. Two children in the control group were admitted to hospital for vomiting and dehydration. Salazar-Lindo 2000 reported four cases of adverse events (two hypokalaemia, one ileus, and one mild fever) that were considered to be possibly related to racecadotril, but none of them were considered serious. Sreenivas 2017 (113 participants) reported that six children from the control group and five from the trial group had serum $\mathrm{K}^{+}$values of less than $3.5 \mathrm{mmol} / \mathrm{L}$, but none in either group had any electrocardiogram changes or symptoms and all recovered without any treatment and had normal serum $\mathrm{K}^{+}$when repeated after 24 hours.

\section{DISCUSSION}

\section{Summary of main results}

We identified seven RCTs (1140 children under five years old) that compared the efficacy and safety of racecadotril to placebo or no

treatment. Trials were conducted in both inpatient and outpatient settings in countries with different levels of income. Compared to placebo or no treatment, racecadotril may reduce the risk of rehydration failure (low-certainty evidence). Data on duration of diarrhoea, number of stools in the first 48 hours are insufficient to reach a conclusion; stool output in the first 48 hours appears to be lower in the two trials measuring this, although the data is not combinable. Length of hospital stay was similar in two studies measuring this, and overall there was no evidence that racecadotril increased overall rate of adverse events (low-certainty evidence). Most adverse events in the racecadotril group were mild or moderate. See Summary of findings for the main comparison.

\section{Overall completeness and applicability of evidence}

Although racecadotril is widely used in Europe, Asia, and South America, only seven trials met the inclusion criteria and were included in this review. More trials, especially on children from developing countries, are needed. A key issue that limits the application of the evidence is the heterogeneity in context, with trials either examining the inpatient or outpatient setting and as such focusing on very different outcomes. 
Failure of rehydration is an important outcome that evaluates the effect of racecadotril on improving the success of rehydration and could directly reflect the clinical value of this drug. Other Cochrane Reviews on children's diarrhoea made failure of rehydration one of the primary outcomes in their efficacy assessment (Hahn 2002; Hartling 2006). However, only two included trials addressed this outcome (García 2016; Sreenivas 2017). Future trials on this topic may consider it as an outcome for efficacy assessment.

The efficacy of racecadotril might be influenced by the severity of the disease, and children with more severe diarrhoea may have better response to treatment. Only two trials measured the severity of diarrhoea using a score system (Gharial 2017; Kang 2016a), and only Gharial 2017 applied it to the inclusion criteria. We roughly stratified participants into two level of severity based on being inpatients or outpatients. Future trials might use a score system to measure the severity of diarrhoea and investigate the impact of disease severity on the efficacy of racecadotril.

This review only included RCTs for safety assessment, but observational studies could also provide important data on safety, especially on reporting serious rare adverse events. Nucera 2006 reported a case of a 3-year-old child (weight: $20 \mathrm{~kg}$ ) with generalized oedema, itching, and aphonia after a two-day treatment with racecadotril. He recovered after discontinuation of racecadotril and treatment with methylprednisolone, hydroxyzine, and adrenaline. Moreno 2009 reported a 12-year-old boy who developed cephalic pruritus 10 minutes after administration of $100 \mathrm{mg}$ of racecadotril. Simple-blinded controlled oral challenge was conducted with increasing dose of racecadotril; 15 minutes later the child suffered a facialis erythema and a generalized urticaria, which illustrated that racecadotril is related to hypersensitivity. The small sample size and short duration of follow-up within the included RCTs limits this review's ability to analyse adverse effects. Further reviews may consider including observational studies for safety assessment.

In applying the evidence to clinical practice, the types of patients should be considered. We only included children under five in the efficacy and safety assessment for a single clinical presentation, leading to a homogeneous data set. However, racecadotril is widely used in other age groups of children and adults. The results of this review might not be applicable to other age groups. In addition, racecadotril has been used for other causes of loose stools, such as in bacterial infectious diarrhoea, and diarrhoea secondary to other conditions like chemotherapy, HIV, malnutrition, etc. The results of this review may not be applicable to those groups of patients.

\section{Certainty of the evidence}

See Summary of findings for the main comparison. The certainty of evidence obtained from current trials ranged from very low to low. Generally, the quality of trial reporting is higher in recently published studies than older ones. There has been improvement with regard to reporting methods of randomization in recent studies but many still did not report how they performed allocation concealment. Future studies should also improve transparency on reporting roles of pharmaceutical companies during the trial if they receive funding from the industry.

\section{Potential biases in the review process}

We used a well-designed search strategy to find clinical studies on this topic. There were, nevertheless, unpublished data that were not available to us; and there might also be existing published studies that were not found by our search strategies. There is consequently the possibility of bias resulting from incomplete data for analysis.

We did not find enough trials to test publication bias using funnel plots. There is, however, a potential for publication bias as some trials were funded by the pharmaceutical industry and the conflict of interest might influence published research results.

\section{Agreements and disagreements with other studies or reviews}

Several recently published systematic reviews have evaluated the efficacy and safety of racecadotril in children (Eberlin 2018; Gordon 2016; Lehert 2011). This trial found that racecadotril might reduce the weight of stool output, which is consistent with previous reviews, but there are more discrepancies. Our review found that there is not sufficient evidence to show racecadotril shortens the duration of diarrhoea or reduces stool frequency, which is inconsistent with other published reviews (Eberlin 2018; Gordon 2016; Lehert 2011). This might mainly be due to different trials being included in the analysis. Lehert 2011 included mostly earlier trials which tend to report significant results on these outcomes. Also, Lehert 2011 was an analysis of individual patient data and included data from five additional studies compared to this review (Calatayud 2009; Cojocaru 2002; Gutiérrez-Castrellón 2010; Melendez-Garcia 2007; Savitha 2006). We excluded Calatayud 2009 and Cojocaru 2002 from this review for being non-randomized studies. We excluded Melendez-Garcia 2007 as the intervention in the control group was kaolin/pectin. We also excluded the unpublished study, Gutiérrez-Castrellón 2010, because some information in the study report we obtained might not be accurate and we failed to obtain further explanation from the author. For example, it reported that non-dehydrated children have much longer disease duration than dehydrated children in the results, which is contrary to common sense; and $\mathrm{Chi}^{2}$ test was used for stool frequency which was, in fact, reported as a continuous variable. Also, the effect size reported in this study was much bigger than other studies, which brings great heterogeneity and might seriously bias the pooled estimates. We do not have access to data of the unpublished study Savitha 2006, which was included by another meta-analysis (Lehert 2011). Compared to Gordon 2016, we did not include Gutiérrez-Castrellón 2010 for the same reasons above. Compared to Eberlin 2018, we did not search for and include RCTs published in Chinese medical journals, as many of them were found not to be RCTs (Wu 2009).

\section{AUTHORS' CONCLUSIONS}

\section{Implications for practice}

Racecadotril seems to be a safe drug but has little benefit in improving acute diarrhoea in children under five years of age. Current evidence does not support routine use of racecadotril in management of acute diarrhoea in children under five outside of the context of placebo-controlled RCTs.

\section{Implications for research}

More RCTs with good study design, reporting quality, and larger sample size are still needed if this drug is to be further investigated as an option. Further trials may consider failure of rehydration as an outcome for evaluating efficacy of racecadotril. They might also stratify participants based on different level of disease severity 
using more direct approaches, such as a severity scoring system, and investigate the impact of disease severity on efficacy.

\section{ACKNOWLEDGEMENTS}

The Academic Editor is Dr Lawrence Mbuagbaw.

We thank the editorial base of the Cochrane Infectious Diseases Group (CIDG) for editorial and methodological support, in particular Lawrence Mbuagbaw, Paul Garner, Anne-Marie Stephani, Deirdre Walshe, and Vittoria Lutje. The CIDG editorial base is funded by UK aid from the UK government for the benefit of low- and middle-income countries (project number 300342-104). The views expressed do not necessarily reflect the UK government's official policies.

We are very grateful to Professor Paul Garner for meeting Yi Liang in 2015 to discuss this review. We are also grateful to Chinese Cochrane Center for helping with this review.

We thank Javier Ortiz-Orendain, Benjamin Koudou, and Bruce Alexander for translating French and Spanish articles. 


\section{R E F E R E N C E S}

\section{References to studies included in this review}

\section{Cézard 2001 \{published data only\}}

Cézard JP, Duhamel JF, Meyer M, Pharaon I, Bellaiche M, Maurage $\mathrm{C}$, et al. Efficacy and tolerability of racecadotril in acute diarrhea in children. Gastroenterology 2001;120(4):799-805.

\section{García 2016 \{unpublished data only\}}

García JXM. Eficacia de racecadotrilo en el tratamiento de la enfermedad diarreica aguda en niños de 3 a 36 meses en el servicio de emergencia del Hospital Vicente Corral Moscoso. Ensayo clínico controlado ciego. Cuenca (Ecuador): University of Cuenca, 2016

\section{Gharial 2017 \{published data only\}}

Gharial J, Laving A, Were F. Racecadotril for the treatment of severe acute watery diarrhoea in children admitted to a tertiary hospital in Kenya. BMJ Open Gastroenterology 2017;4(1):e000124.

\section{Kang 2016a \{published data only\}}

Kang G, Thuppal SV, Srinivasan R, Sarkar R, Subashini B, Venugopal $S$, et al. Racecadotril in the management of rotavirus and non-rotavirus diarrhea in under-five children: two randomized, double-blind, placebo-controlled trials. Indian Pediatrics 2016;53(7):595-600.

\section{Kang 2016b \{published data only\}}

Kang G, Thuppal SV, Srinivasan R, Sarkar R, Subashini B, Venugopal $S$, et al. Racecadotril in the management of rotavirus and non-rotavirus diarrhea in under-five children: two randomized, double-blind, placebo-controlled trials. Indian Pediatrics 2016;53(7):595-600.

\section{Salazar-Lindo 2000 \{published data only\}}

Salazar-Lindo E, Santisteban-Ponce J, Chea-Woo E, Gutierrez M. Racecadotril in the treatment of acute watery diarrhea in children. New England Journal of Medicine 2000;343(7):463-7.

\section{Santos 2009 \{published data only\}}

Santos M, Marañón R, Miguez C, Vázquez P, Sánchez C. Use of racecadotril as outpatient treatment for acutegastroenteritis: a prospective, randomized, parallel study. Journal of Pediatrics 2009;155(1):62-7.

\section{Sreenivas 2017 \{published data only\}}

Sreenivas SK, Lakshmi M, Pavitra NA. Efficacy and safety of racecadotril as an adjunct to oral rehydration therapy for acute watery diarrhea in children. Indian Journal of Child Health 2017;4(1):68-71.

\section{References to studies excluded from this review}

\section{Calatayud 2009 \{published data only\}}

Calatayud G, Simón G, Castro L, Sebastián M, Castillo A, Abunaji Y, et al. Effectiveness of racecadotril in the treatment of acute gastroenteritis [Efectividad de racecadotrilo en el tratamientode la gastroenteritis aguda]. Acta Pediatrica Espanola 2009;67(3):117-22.
Chacón 2010 \{published data only\}

Chacón J. Analysis of factors influencing the overall effect of racecadotril on childhood acute diarrhea. Results from a realworld and post-authorization surveillance study in Venezuela. Therapeutics and Clinical Risk Management 2010;6:293-99.

\section{Cojocaru 2002 \{published data only\}}

Cojocaru B, Bocquet N, Timsit S, Wille C, Boursiquot C, Marcombes $F$, et al. Racecadotril in the treatment of acute watery diarrhea in children [Effet du racécadotril sur le recours aux soins dans le traitement des diarrhées aiguës du nourrisson et de l'enfant]. Archives de Pediatrie 2002;9(8):774-9.

Melendez-Garcia 2007 \{published data only\} Melendez-Garcia JM, Rodriguez JT. Racecadotril for the treatment of diarrhoea in children [Racecadotril en el tratamiento de la diarreaaguda en ninos]. Revista de la Facultad de Medicina (Guatemala) 2007;4:25-8.

Michael 2014 \{published data only\}

Michael SS, Abdelhaleem Ali AM, Ezzat DA, Tayel SA. Evaluation of racecadotril in treatment of acute diarrhea in children. Asian Journal of Pharmaceutical and Clinical Research 2014;7(4):227-30.

NCT03463512 \{unpublished data only\} NCT03463512. Controlled study to evaluate the efficacy and safety of racecadotril in infants, children and adolescents with acute diarrhea. clinicaltrials.gov/ct2/show/nct03463512 (last update posted: 27 September 2018).

\section{Rautenberg 2012 \{published data only\}}

Rautenberg TA, Zerwes U, Foerster D, Aultman R. Evaluating the cost utility of racecadotril for the treatment of acute watery diarrhea in children: The RAWD model. ClinicoEconomics and Outcomes Research 2012;4(1):109-16.

Tiholova 2010 \{published data only\}

Tiholova M, Tchipeva R. Treatment of acute watery diarrhoea with racecadotril in children. Proceedings of the VI national congress of pharmacology. Autonomic \& Autacoid Pharmacology 2010;30:1-65.

Torrez 2013 \{unpublished data only\}

Torrez J, Soria R, Grandy G. Racecadotril, a good alternative in the management of acute watery diarrhea in children. Pediatric Research 2013;73(3):379.

Turck 1999 \{published data only\}

Turck D, Berard H, Fretault N, Lecomte JM. Comparison of racecadotril and loperamide in children with acute diarrhoea. Alimentary Pharmacology \& Therapeutics 1999;Suppl 6:27-32.

\section{References to studies awaiting assessment}

ChiCTR-TRC-12002199 \{unpublished data only\}

ChiCTR-TRC-12002199. Racecadotril granules for acute diarrhea in children: multicenter randomized controlled clinical trial 
[A multicenter, randomized, controlled study to evaluate the efficacy and safety of racecadotril granules in children with acute diarrhea]. www.chictr.org.cn/hvshowproject.aspx? id $=2768$.

\section{Gutiérrez-Castrellón 2010 \{unpublished data only\}}

Gutiérrez-Castrellón P, Gallardo BL, Alejandra-Ortiz A, Hernandez-Contreras J, Bastidas MA, Mayans JR, et al. Randomized, double blind, placebo controlled, clinical trial on the safety, efficacy and pharmacoeconomic analysis of racecadotril in children with acute diarrhea in Mexico. Data on file.

\section{IRCT201607131264N8 \{unpublished data only\}}

IRCT201607131264N8. Efficacy and safety of racecadotril in treatment of acute diarrhea in children 1 months to 5-years [Efficacy and safety of enkefalinase inhibitor racecadotril in decreasing the duration and frequency of acute diarrhea in children 1 months to 5 years]. en.irct.ir/trial/495 (registration date 12 May 2017)

\section{Savitha 2006 \{unpublished data only\}}

Savitha MR. Racecadotrial - a novel drug for treatment of acute watery diarrhoea in Indian children. Karnataka Pedicon 2005 Conference Abstracts (data not found).

\section{Additional references}

\section{Abramson 1993}

Abramson JS, Ginver LB, Woods CR. Bismuth in infants with watery diarrhea. New England Journal of Medicine 1993;329(23):1742-3.

\section{Alam 2003}

Alam NH, Ashraf H, Khan WA, Karim MM, Fuchs GJ. Efficacy and tolerability of racecadotril in the treatment of cholera in adults: a double blind, randomised, controlled clinical trial. Gut 2003;52:1419-23.

\section{Bioprojet Pharma 2007}

Bioprojet Pharma. Proposal for the inclusion of racecadotril in the WHO model Llst of essential medicines. archives.who.int/ eml/expcom/children/Applications/racecadotril/ Proposal_racecadotril.pdf (accessed 1 May 2018).

\section{Coffin 2014}

Coffin B, Hamza H, Vetel JM, Lehert P. Racecadotril in the treatment of acute diarrhoea in adults. An individual patient data based meta-analysis. International Journal of Clinical Medicine 2014;5(7):345-60.

\section{Deeks 2011}

Deeks JJ, Higgins JPT, Altman DG. Chapter 9: Analysing data and undertaking meta-analyses. In: Higgins JP, Green S, editor(s). Cochrane Handbook for Systematic Reviews of Interventions Version 5.1.0 (updated March 2011). The Cochrane Collaboration, 2011. Available from handbook.cochrane.org.

\section{Eberlin 2018}

Eberlin M, Chen M, Mueck T, Däbritz J. Racecadotril in the treatment of acute diarrhea in children: a systematic, comprehensive review and meta-analysis of randomized controlled trials. BMC Pediatrics 2018;18(1):124.

\section{Egger 1997}

Egger M, Davey Smith G, Schneider M, Minder C. Bias in meta-analysis detected by a simple, graphical test. BMJ 1997;315(7109):629-34.

\section{Florez 2018}

Florez ID, Veroniki AA, Al Khalifah R, Yepes-Nuñez JJ, Sierra JM, Vernooij RWM, et al. Comparative effectiveness and safety of interventions for acute diarrhea and gastroenteritis in children: a systematic review and network meta-analysis. PLoS One 2018;13(12):e0207701.

\section{Gordon 2016}

Gordon M, Akobeng A. Racecadotril for acute diarrhoea in children:systematic review and meta-analyses. Archives of Disease in Childhood 2016;101(3):234-40.

\section{GRADEpro GDT [Computer program]}

McMaster University (developed by Evidence Prime). GRADEpro GDT. Version accessed 5 June 2018. Hamilton (ON): McMaster University (developed by Evidence Prime), 2015.

\section{Guarino 2014}

Guarino A, Ashkenazi S, Gendrel D, Vecchio AL, Shamir R, Szajewska H. European Society for Pediatric Gastroenterology, Hepatology, and Nutrition/European Society for PediatricInfectious Diseases Evidence-Based Guidelines for the Management of Acute Gastroenteritis in Children in Europe: Update 2014. Journal of Pediatric Gastroenterology and Nutrition 2014;59(1):132-52.

\section{Guyatt 2011a}

Guyatt G, Oxman AD, Akl EA, Kunz R, Vist G, BrozekJ, et al. GRADE guidelines: 1. Introduction-GRADEevidence profiles and summary of findings tables. Journal of Clinical Epidemiology 2011;64(4):383-94.

\section{Guyatt 2011b}

Guyatt GH, Oxman AD, Vist G, Kunz R, Brozek J, Alonso-Coello P, et al. GRADE guidelines: 4 . Rating the quality of evidence-study limitations (risk of bias). Journal of Clinical Epidemiology 2011;64(4):407-15.

\section{Hahn 2002}

Hahn S, Kim Y, Garner P. Reduced osmolarity oral rehydration solution for treating dehydration caused by acute diarrhoea in children. Cochrane Database of Systematic Reviews 2002, Issue 1. [DOI: 10.1002/14651858.CD002847]

\section{Hartling 2006}

Hartling L, Bellemare S, Wiebe N, Russell KF, Klassen TP, Craig WR. Oral versus intravenous rehydration for treating dehydration due to gastroenteritis in children. Cochrane Database of Systematic Reviews 2006, Issue 3. [DOI: 10.1002/14651858.CD004390.pub2] 


\section{Higgins 2011}

Higgins JPT, Altman DG, Sterne JAC. Chapter 8: Assessing risk of bias in included studies. In: Higgins JP, Green S, editor(s). Cochrane Handbook for Systematic Reviews of Interventions Version 5.1.0 (updated March 2011). The Cochrane Collaboration, 2011. Available from handbook.cochrane.org.

\section{Lefebvre 2011}

Lefebvre C, Manheimer E, Glanville J. Chapter 6: Searching for studies. In: Higgins JPT, Green S (editors). Cochrane Handbook for Systematic Reviews of Interventions Version 5.1.0 (updated March 2011). The Cochrane Collaboration, 2011. Available from handbook.cochrane.org.

\section{Lehert 2011}

Lehert P, Chéron G, Calatayud GA, Cézard JP, Castrellón PG, Garcia JM, et al. Racecadotril for childhood gastroenteritis: an individual patient data meta-analysis. Digestive and Liver Disease 2011;43(9):707-13.

\section{Lewis 2011}

Lewis K. Vesikari Clinical Severity Scoring System Manual, Version 1.3. www.path.org/publications/files/ VAD_vesikari_scoring_manual.pdf (accessed 10 June 2018).

\section{Maldonado 2006}

Maldonado J. New perspectives on acute diarrhea in the breast fed infant: racecadotril. Ars Pharmaceutica 2006;47(3):251-63.

\section{Moreno 2009}

Moreno A, Mira JM. Acute urticaria due to acetorphan (Abstract). Pediatric Allergy and Immunology. Venice, Italy, 2009; Vol. 20, issue Issue Supplement s 20:37.

\section{Murad 2017}

Murad MH, Mustafa RA, Schünemann HJ, Sultan S, Santesso N. Rating the certainty in evidence in the absence of a single estimate of effect. Evidence-based Medicine 2017;22(3):85-7.

\section{NICE 2009}

National Institute for Health and Care Excellence. Diarrhoea and vomiting in children: Diarrhoea and vomiting caused by gastroenteritis: diagnosis, assessment and management in children younger than 5 years. Clinical guideline [CG84] Published date: April 2009. www.nice.org.uk/guidance/cg84 (accessed 22 June 2018).

\section{Nucera 2006}

Nucera E, Schiavino D, Altomonte G, Buonomo A, Sabato V, Patriarca G. Hypersensitivity to racecadotril: a case report. European Journal of Pediatrics 2006;165:418-9.

\section{Parashar 2003}

Parashar UD, Hummelman EG, Bresee JS, Miller MA, Glass RI. Global illness and deaths caused by rotavirus disease in children. Emerging Infectious Diseases 2003;9(5):565-72.

\section{Primi 1999}

Primi MP, Bueno L, Baumer P, Berard H, Lecomte JM. Racecadotril demonstrates intestinal antisecretory activity in vivo. Alimentary Pharmacology \& Therapeutics 1999;Suppl 6:3-7.

\section{Review Manager 5 [Computer program]}

Nordic Cochrane Centre, The Cochrane Collaboration. Review Manager 5 (RevMan 5). Version 5.3. Copenhagen: Nordic Cochrane Centre, The Cochrane Collaboration, 2014.

\section{Schwartz 2000}

Schwartz JC. Racecadotril: a new approach to the treatment of diarrhoea. International Journal of Antimicrobial Agents 2000;14(1):75-9.

\section{Schünemann 2011}

SchünemannHJ, Oxman AD, Vist GE, Higgins JPT, Deeks JJ, Glasziou P, Guyatt GH. Chapter 12: Interpreting results and drawing conclusions. In: Higgins JP, Green S, editor(s). Cochrane Handbook for Systematic Reviews of Interventions Version 5.1.0 (updated March 2011). The Cochrane Collaboration, 2011. Available from handbook.cochrane.org.

\section{Szajewska 2007}

Szajewska H, Ruszczynski M, Chmielewska A, Wieczorek J. Systematic review: racecadotril in the treatment of acute diarrhoea in children. Alimentary Pharmacology \& Therapeutics 2007;26(6):807-13.

\section{Tormo 2008}

Tormo R, Polanco I, Salazar-Lindo E, Goulet O. Acute infectious diarrhoea in children: new insights in antisecretory treatment with racecadotril. Acta Paediatrica 2008;97(8):1008-15.

\section{UNICEF/WHO 2004}

Department of Child and Adolescent Health and Development, World Health Organization. Clinical management of acute diarrhoea: WHO/UNICEF joint statement[WHO/FCH/ CAH/04.7;UNICEF/PD/Diarrhoea/01]. www.who.int/iris/ handle/10665/68627 (accessed 5 July 2010).

\section{WHO 1999}

World Health Organization, Dept. of Child and Adolescent Health and Development. The evolution of diarrhoeal and acute respiratory disease control at WHO : achievements 1980-1995 in research, development and implementation. www.who.int/iris/ handle/10665/66014 (accessed 22 June 2018).

\section{WHO 2005}

Department of Child and Adolescent Health and Development, World Health Organization. The treatment of diarrhoea : a manual for physicians and other senior health workers - 4th rev. www.who.int/iris/handle/10665/43209 (accessed 1 May 2017).

\section{WHO 2008}

World Health Organization. Global networks for surveillance of rotavirus gastroenteritis, 2001-2008. Weekly Epidemiological Record 2008;83(47):421-8.

\section{WHO 2017}

World Health Organization. Diarrhoeal disease. www.who.int/ mediacentre/factsheets/fs330/en/ (accessed 1 May 2017).

\section{Wu 2009}

Wu T, Li Y, liu G, Moher D. Randomized trials published in some Chinese journals: how many are randomized?. Trials 2009;10:46. 


\section{References to other published versions of this review \\ Liang 2011}

Liang Y, Zhang L, Zeng L, Wen J. Racecadotril for acute diarrhoea in children. Cochrane Database of Systematic Reviews 2011, Issue 10. [DOI: 10.1002/14651858.CD009359]

\section{CHARACTERISTICS OF STUDIES}

Characteristics of included studies [ordered by study ID]

\section{Cézard 2001}

\begin{tabular}{|c|c|}
\hline Methods & $\begin{array}{l}\text { Randomized, double-blinded, placebo-controlled trial } \\
\text { Length of follow-up: till recovery }\end{array}$ \\
\hline \multirow[t]{7}{*}{ Participants } & Number: 168 \\
\hline & Inclusion criteria: \\
\hline & $\begin{array}{l}\text { Children of both genders aged } 3 \text { months to } 4 \text { years who had watery diarrhoea ( } 3 \text { or more watery stools } \\
\text { per day) of less than } 72 \text { hours' duration. }\end{array}$ \\
\hline & Before inclusion, each patient had to pass at least 1 watery stool at the hospital. \\
\hline & Exclusion criteria: \\
\hline & $\begin{array}{l}\text { Patients who had chronic diarrhoea, a weight-for-age deficit of } 20 \% \text { or more of National Center for } \\
\text { Health Statistics standards, or a systemic illness or had received an antibiotic, antidiarrhoeal drug, or } \\
\text { acetylsalicylic acid within the preceding } 48 \text { hours. }\end{array}$ \\
\hline & Missing data: 47 participants \\
\hline \multirow[t]{3}{*}{ Interventions } & Group 1: 86 received racecadotril additional to oral rehydration \\
\hline & Group 2: 82 received placebo additional to oral rehydration \\
\hline & Racecadotril was given $1.5 \mathrm{mg} / \mathrm{kg}$ of body weight, orally every 8 hours. \\
\hline Outcomes & $\begin{array}{l}\text { - Stool output in the first } 48 \text { hours. Stool weight was measured every } 12 \text { hours for the first } 48 \text { hours by } \\
\text { subtracting the weight of pre-weighed diapers from that of used diapers. } \\
\text { - Stool output during the first } 24 \text { hours } \\
\text { - Na/K ratio of urine } \\
\text { - Duration of diarrhoea. The time to recovery was analysed using Kaplan-Meier curves } \\
\text { - Number and characteristics of stools. } \\
\text { - Tolerability }\end{array}$ \\
\hline
\end{tabular}

Notes Location: France

Source of funding was not reported, but some of the authors were from the pharmaceutical industry.

\section{Risk of bias}

\begin{tabular}{lll}
\hline Bias & Authors' judgement & Support for judgement \\
\hline $\begin{array}{l}\text { Random sequence genera- } \\
\text { tion (selection bias) }\end{array}$ & Unclear risk & Method of random sequence generation was not reported \\
\hline $\begin{array}{l}\text { Allocation concealment } \\
\text { (selection bias) }\end{array}$ & Unclear risk & Not mentioned \\
\hline
\end{tabular}




\section{Cézard 2001 (Continued)}

Blinding of participants Low risk Double-blinded; both drug treatments were given as granules of the same apand personnel (perforpearance and taste

mance bias)

All outcomes

\begin{tabular}{lll}
\hline $\begin{array}{l}\text { Blinding of outcome as- } \\
\text { sessment (detection bias) } \\
\text { All outcomes }\end{array}$ & Low risk & Double-blinded placebo-controlled \\
\hline $\begin{array}{l}\text { Incomplete outcome data } \\
\begin{array}{l}\text { (attrition bias) } \\
\text { All outcomes }\end{array}\end{array}$ & High risk & $\begin{array}{l}\text { The total amount of attrition was 28\% (more than 20\%). The number of loss to } \\
\text { follow-up was balanced in 2 groups but the reasons for loss to follow was not } \\
\text { balanced. }\end{array}$ \\
\hline $\begin{array}{l}\text { Selective reporting (re- } \\
\text { porting bias) }\end{array}$ & Unclear risk & $\begin{array}{l}\text { The trial protocol is not available. It was unknown if outcomes were selectively } \\
\text { reported. }\end{array}$ \\
\hline
\end{tabular}

Other bias

High risk

Source of funding was not reported, but some of the authors were from the pharmaceutical industry.

García 2016

\begin{tabular}{|c|c|}
\hline Methods & $\begin{array}{l}\text { Randomized, double-blinded, placebo-controlled trial } \\
\text { Length of follow-up: } 3 \text { days }\end{array}$ \\
\hline \multirow[t]{5}{*}{ Participants } & $\begin{array}{l}\text { Number: } 92 \\
\text { Inclusion criteria: }\end{array}$ \\
\hline & $\begin{array}{l}\text { Children aged } 3 \text { months to } 36 \text { months with acute diarrhoea (less than } 14 \text { days' duration) without dehy- } \\
\text { dration or with mild to moderate dehydration. Diarrhoea was defined as at least } 3 \text { stools with a change } \\
\text { in the consistency. }\end{array}$ \\
\hline & Exclusion criteria: \\
\hline & $\begin{array}{l}\text { Failed to tolerate oral administration; previous administration of drugs that might interact with } \\
\text { racecadotril, antibiotics or other therapy for diarrhoea; children with ostomies or with short gut syn- } \\
\text { drome. }\end{array}$ \\
\hline & Missing data: 13 children \\
\hline
\end{tabular}

Interventions

Group 1: 46 children were randomized to receive oral rehydration solution plus racecadotril;

Group 2: 46 children were randomized to receive oral rehydration solution plus placebo

Racecadotril was given $10 \mathrm{mg}$ for children with a weight under $9 \mathrm{~kg}, 20 \mathrm{mg}$ for children with a weight of 9 to $13 \mathrm{~kg}$, and $30 \mathrm{mg}$ for patients with a weight of 14 to $27 \mathrm{~kg}$, every 8 hours for 72 hours.

\begin{tabular}{ll}
\hline Outcomes & Number of stools \\
- Consistency of stools \\
- Need for another emergency room service or primary care consultation \\
- Compliance \\
- Participants completing the trial \\
- Cure \\
\hline Notes & Location: Ecuador \\
& Source of funding: unclear \\
\hline
\end{tabular}


García 2016 (Continued)

Baseline imbalance in the age of the groups $(P=0.043)$

\section{Risk of bias}

\begin{tabular}{|c|c|c|}
\hline Bias & Authors' judgement & Support for judgement \\
\hline $\begin{array}{l}\text { Random sequence genera- } \\
\text { tion (selection bias) }\end{array}$ & Low risk & $\begin{array}{l}\text { Using the site www.randomization.com which generated groups " } \mathrm{A} \text { " and "B". } \\
\text { The list was displayed. }\end{array}$ \\
\hline $\begin{array}{l}\text { Allocation concealment } \\
\text { (selection bias) }\end{array}$ & Unclear risk & Not mentioned \\
\hline $\begin{array}{l}\text { Blinding of participants } \\
\text { and personnel (perfor- } \\
\text { mance bias) } \\
\text { All outcomes }\end{array}$ & Low risk & $\begin{array}{l}\text { Patients and personnel in the hospital were blinded. } \\
\text { Capsules were identical in shape and colour. }\end{array}$ \\
\hline $\begin{array}{l}\text { Blinding of outcome as- } \\
\text { sessment (detection bias) } \\
\text { All outcomes }\end{array}$ & High risk & $\begin{array}{l}\text { The researcher who delivered the medication knew the content of the medi- } \\
\text { cine bottle. }\end{array}$ \\
\hline $\begin{array}{l}\text { Incomplete outcome data } \\
\text { (attrition bias) } \\
\text { All outcomes }\end{array}$ & High risk & $\begin{array}{l}45 / 46 \text { patients completed the trial in the intervention group; } 34 / 46 \text { patients in } \\
\text { the control group completed the trial (loss to follow-up }>20 \% \text { ); reason for loss } \\
\text { to follow-up: did not respond to phone call; no intention-to-treat analysis. }\end{array}$ \\
\hline $\begin{array}{l}\text { Selective reporting (re- } \\
\text { porting bias) }\end{array}$ & Unclear risk & No information about research protocol \\
\hline Other bias & Unclear risk & Unclear information about the source of funding \\
\hline
\end{tabular}

Gharial 2017

Methods Randomized, double-blinded, placebo-controlled trial

Length of follow-up: not reported

Participants

Number: 120

Inclusion criteria:

Children aged 3 to 60 months with acute diarrhoea, as evidenced by a Vesikari score of $>11$

Exclusion criteria:

Children who had severe vomiting; those with a clinical diagnosis of dysentery or a known diagnosis of liver or renal failure; children who had prescriptions of probiotics or any other antidiarrhoeal medication.

Missing data: 9 participants

Group 1: 60 children received racecadotril additional to oral rehydration or intravenous rehydration and zinc

Group 2: 60 children received oral rehydration or venous rehydration and zinc

They received either intravenous fluids as per WHO plan C $(30 \mathrm{~mL} / \mathrm{kg}$ followed by $70 \mathrm{~mL} / \mathrm{kg}$ over 1 and 5 hours, respectively, in infants and over 30 min and 2.5 hours for those over 12 months of age) or low 
Gharial 2017 (Continued)

osmolality oral rehydration solution as per WHO plan B ( $75 \mathrm{~mL} / \mathrm{kg}$ over 4 hours). Zinc was prescribed at 10 to $20 \mathrm{mg} /$ day.

The test arm received racecadotril at a dose recommended by the manufacturer: $10 \mathrm{mg}$ per dose for children below 12 months of age and $30 \mathrm{mg}$ for those over 12 months of age.

- Number of stools in the first 48 hours after introduction of the drug. The difference in the median
number of stools on intention-to-treat analysis revealed no statistically significant difference.
- Duration of inpatient stay. This was measured as the number of days from the start of the medication
to the day of discharge as determined by the attending physician.
- Duration of illness. This was defined as the duration from the time of introduction of the drug to the
appearance of $\leq 3$ formed stools in 24 hours.
- Adverse events associated with racecadotril.

Notes Location: Kenya

The trial received part of its funding from pharmaceutical industry.

\section{Risk of bias}

\begin{tabular}{lll}
\hline Bias & Authors' judgement & Support for judgement \\
\hline $\begin{array}{l}\text { Random sequence genera- } \\
\text { tion (selection bias) }\end{array}$ & Low risk & $\begin{array}{l}\text { A computer program was used to generate random numbers in blocks with } \\
\text { varying sizes. }\end{array}$ \\
\hline $\begin{array}{l}\text { Allocation concealment } \\
\text { (selection bias) }\end{array}$ & Low risk & $\begin{array}{l}\text { Not reported in the article. We contacted the author for additional informa- } \\
\text { tion. The allocation of children was concealed from the primary researcher as } \\
\text { it was carried out by the trial pharmacist; and randomization of each child and } \\
\text { confirmation of receipt of prescription was concealed in tamper-proof brown } \\
\text { envelopes. }\end{array}$ \\
\hline
\end{tabular}

\begin{tabular}{|c|c|c|}
\hline $\begin{array}{l}\text { Blinding of participants } \\
\text { and personnel (perfor- }\end{array}$ & Low risk & $\begin{array}{l}\text { The medication and placebo were packed in tamper-proof brown bags, sealec } \\
\text { and labelled by a trial pharmacist based off-site. }\end{array}$ \\
\hline
\end{tabular}

\begin{tabular}{|c|c|c|}
\hline $\begin{array}{l}\text { Blinding of outcome as- } \\
\text { sessment (detection bias) } \\
\text { All outcomes }\end{array}$ & Low risk & Double-blinded placebo-controlled \\
\hline $\begin{array}{l}\text { Incomplete outcome data } \\
\text { (attrition bias) } \\
\text { All outcomes }\end{array}$ & Low risk & $\begin{array}{l}\text { The loss to follow-up was balanced across the } 2 \text { groups, with } 5 / 60 \text { lost from } \\
\text { the intervention and } 4 / 60 \text { from the control group. The total amount of attrition } \\
\text { was less than } 20 \% \text {. }\end{array}$ \\
\hline $\begin{array}{l}\text { Selective reporting (re- } \\
\text { porting bias) }\end{array}$ & Low risk & $\begin{array}{l}\text { The trial was registered in Pan African Clinical Trial Registry (PACTR) and all } \\
\text { outcomes from the protocol were reported. }\end{array}$ \\
\hline Other bias & Low risk & $\begin{array}{l}\text { Received part of its funding from pharmaceutical industry but the conclusion } \\
\text { did not favour the company. }\end{array}$ \\
\hline
\end{tabular}

\section{Kang 2016a}

\begin{tabular}{ll}
\hline Methods & Randomized, double-blinded, placebo-controlled trial \\
& Length of follow-up: not reported \\
\hline Participants & Number: 130 \\
\hline
\end{tabular}


Inclusion criteria:

Children aged 3 to 59 months with acute diarrhoea ( $\geq 3$ episodes of loose, watery stools in last 24 hours for less than 3 days); the trial physician recommended hospitalization for management of diarrhoea (inpatient trial).

\section{Exclusion criteria:}

Children with weight less than $5 \mathrm{~kg}$, with severe co-existing diseases, severe malnutrition, chronic diarrhoea, or with blood and mucus in stool.

Children received antibiotics, probiotics, steroids, herbal medicines, antiemetics, anti-motility or other treatment of unknown nature.

Missing data: 6 participants

Interventions Group 1: 65 children received racecadotril additional to WHO standard of care.

Group 2: 65 children received placebo additional to WHO standard of care.

- Median duration of diarrhoea. Defined as the time from onset of diarrhoea to the time of resolution,
identified as the time of the last abnormal stool or the start of a 12-hour period with no stool. This was
recorded by a trial nurse in the hospital and by mother's recall during the field worker's visit in the
community-based trial
- Diarrhoeal stool volume
- Rehydration requirement
- Presence of vomiting after administering the drug or placebo

Notes Location: India

Source of funding: Swedish International Development Agency (governmental organization)

\section{Risk of bias}

\begin{tabular}{|c|c|c|}
\hline Bias & Authors' judgement & Support for judgement \\
\hline $\begin{array}{l}\text { Random sequence genera- } \\
\text { tion (selection bias) }\end{array}$ & Low risk & $\begin{array}{l}\text { Individual randomization codes were generated by a statistician not associat- } \\
\text { ed with this trial }\end{array}$ \\
\hline $\begin{array}{l}\text { Allocation concealment } \\
\text { (selection bias) }\end{array}$ & Low risk & $\begin{array}{l}\text { Sealed envelopes with randomization codes were given directly to the hospital } \\
\text { pharmacy }\end{array}$ \\
\hline $\begin{array}{l}\text { Blinding of participants } \\
\text { and personnel (perfor- } \\
\text { mance bias) } \\
\text { All outcomes }\end{array}$ & Low risk & $\begin{array}{l}\text { Double-blinded. The hospital pharmacy provided identically packed trial drug } \\
\text { or placebo }\end{array}$ \\
\hline $\begin{array}{l}\text { Blinding of outcome as- } \\
\text { sessment (detection bias) } \\
\text { All outcomes }\end{array}$ & Low risk & Double-blinded placebo-controlled \\
\hline $\begin{array}{l}\text { Incomplete outcome data } \\
\text { (attrition bias) } \\
\text { All outcomes }\end{array}$ & Low risk & $\begin{array}{l}\text { The loss to follow-up was balanced across the } 2 \text { groups, with } 4 / 65 \text { lost from } \\
\text { the intervention and } 2 / 65 \text { from the control group. The total amount of attrition } \\
\text { was less than } 20 \%\end{array}$ \\
\hline $\begin{array}{l}\text { Selective reporting (re- } \\
\text { porting bias) }\end{array}$ & Low risk & The trial was registered and all important outcomes were reported \\
\hline Other bias & Low risk & Not funded by pharmaceutical industry \\
\hline
\end{tabular}


Kang 2016b

\begin{tabular}{|c|c|}
\hline Methods & $\begin{array}{l}\text { Randomized, double-blinded, placebo-controlled trial } \\
\text { Length of follow-up: not reported }\end{array}$ \\
\hline Participants & $\begin{array}{l}\text { Number: } 199 \\
\text { Inclusion criteria: } \\
\text { Children aged } 3 \text { to } 59 \text { months with acute diarrhoea ( } \geq 3 \text { episodes of loose, watery stools in last } 24 \text { hours } \\
\text { for less than } 3 \text { days); the trial physician recommended management of diarrhoea at home. } \\
\text { Exclusion criteria: } \\
\text { Children with weight less than } 5 \mathrm{~kg} \text {, with severe co-existing diseases, severe malnutrition, chronic diar- } \\
\text { rhoea, or with blood and mucus in stool. } \\
\text { Children received antibiotics, probiotics, probiotics, steroids, herbal medicines, antiemetics, an- } \\
\text { ti-motility or other treatment of unknown nature. } \\
\text { Missing data: } 3 \text { patients }\end{array}$ \\
\hline Interventions & $\begin{array}{l}\text { Group 1: } 102 \text { children received racecadotril additional to WHO standard of care. } \\
\text { Group 2: } 97 \text { children received placebo additional to WHO standard of care. }\end{array}$ \\
\hline Outcomes & $\begin{array}{l}\text { - Median duration of diarrhoea. Defined as the time from onset of diarrhoea to the time of resolution, } \\
\text { identified as the time of the last abnormal stool or the start of a 12-hour period with no stool. This was } \\
\text { recorded by a trial nurse in the hospital and by mother's recall during the field worker's visit in the } \\
\text { community-based trial. } \\
\text { - Presence of vomiting after administering the drug or placebo. } \\
\text { - History of day care or hospital visit, or both, during the period of observation. }\end{array}$ \\
\hline
\end{tabular}

Notes Location: India

Source of funding: Swedish International Development Agency (governmental organization)

\section{Risk of bias}

\begin{tabular}{|c|c|c|}
\hline Bias & Authors' judgement & Support for judgement \\
\hline $\begin{array}{l}\text { Random sequence genera- } \\
\text { tion (selection bias) }\end{array}$ & Low risk & $\begin{array}{l}\text { Individual randomization codes were generated by a statistician not associat- } \\
\text { ed with this trial }\end{array}$ \\
\hline $\begin{array}{l}\text { Allocation concealment } \\
\text { (selection bias) }\end{array}$ & Low risk & $\begin{array}{l}\text { Sealed envelopes with randomization codes were given directly to the hospital } \\
\text { pharmacy }\end{array}$ \\
\hline $\begin{array}{l}\text { Blinding of participants } \\
\text { and personnel (perfor- } \\
\text { mance bias) } \\
\text { All outcomes }\end{array}$ & Low risk & $\begin{array}{l}\text { Double-blinded. The hospital pharmacy provided identically packed trial drug } \\
\text { or placebo }\end{array}$ \\
\hline $\begin{array}{l}\text { Blinding of outcome as- } \\
\text { sessment (detection bias) } \\
\text { All outcomes }\end{array}$ & Low risk & Double-blinded placebo-controlled \\
\hline $\begin{array}{l}\text { Incomplete outcome data } \\
\text { (attrition bias) } \\
\text { All outcomes }\end{array}$ & Low risk & $\begin{array}{l}\text { The loss to follow-up was balanced across the } 2 \text { groups, with } 3 / 102 \text { lost from } \\
\text { the intervention and 0/97 from the control group. The total amount of attrition } \\
\text { was less than } 20 \%\end{array}$ \\
\hline
\end{tabular}


Kang 2016b (Continued)

Selective reporting (re- Low risk The trial was registered and all important outcomes were reported porting bias)

Other bias Low risk Not funded by pharmaceutical industry

\section{Salazar-Lindo 2000}

\begin{tabular}{|c|c|}
\hline Methods & $\begin{array}{l}\text { Randomized, double-blind, placebo-controlled trial } \\
\text { Length of follow-up: } 5 \text { days }\end{array}$ \\
\hline Participants & $\begin{array}{l}\text { Number: } 135 \\
\text { Inclusion criteria: } \\
\text { Boys aged } 3 \text { to } 35 \text { months who were hospitalized for dehydration, having acute watery diarrhoea for } 5 \\
\text { days or less. } \\
\text { Exclusion criteria: } \\
\text { Boys with blood in the stool, severe dehydration, or any serious concomitant illness. } \\
\text { Boys treated with antibiotics, other anti-diarrhoeal drugs, or aspirin. } \\
\text { Boys had blood in their stools during the first } 24 \text { hours. } \\
\text { Missing data: } 23 \text { participants }\end{array}$ \\
\hline Interventions & $\begin{array}{l}\text { Group 1: } 68 \text { received racecadotril additional to oral rehydration } \\
\text { Group 2: } 67 \text { received placebo additional to oral rehydration } \\
\text { Racecadotril was given } 1.5 \mathrm{mg} / \mathrm{kg} \text { of body weight, orally every } 8 \text { hours. }\end{array}$ \\
\hline Outcomes & $\begin{array}{l}\text { - Stool output in the first } 48 \text { hours. Stool were collected with pre-weighed diapers; care was taken to } \\
\text { ensure that stools were collected separately from urine. } \\
\text { - Total stool output. } \\
\text { - Duration of diarrhoea. The assessment was made at the time of recovery or at the end of } 5 \text { days, if the } \\
\text { child had not recovered by this time. } \\
\text { - Total intake of oral rehydration solution. }\end{array}$ \\
\hline
\end{tabular}

Lotes
Source of funding: supported by the pharmaceutical industry but failed to report the role of the phar-
maceutical company during the trial

\section{Risk of bias}

\begin{tabular}{lll}
\hline Bias & Authors' judgement & Support for judgement \\
\hline $\begin{array}{l}\text { Random sequence genera- } \\
\text { tion (selection bias) }\end{array}$ & Unclear risk & Method of random sequence generation was not reported \\
\hline $\begin{array}{l}\text { Allocation concealment } \\
\text { (selection bias) }\end{array}$ & Unclear risk & Not mentioned \\
\hline
\end{tabular}


Salazar-Lindo 2000 (Continued)

Blinding of participants Low risk Double-blinded; both treatments were administered as saccharose-containing and personnel (perforpowders of identical appearance and taste. mance bias)

All outcomes

\begin{tabular}{lll}
\hline $\begin{array}{l}\text { Blinding of outcome as- } \\
\text { sessment (detection bias) } \\
\text { All outcomes }\end{array}$ & Low risk & Double-blinded placebo-controlled \\
\hline $\begin{array}{l}\text { Incomplete outcome data } \\
\text { (attrition bias) } \\
\text { All outcomes }\end{array}$ & Low risk & $\begin{array}{l}\text { The loss to follow-up was balanced across the } 2 \text { groups, with } 9 / 68 \text { lost from the } \\
\text { intervention and } 14 / 67 \text { from the control group. The total amount of attrition } \\
\text { was less than } 20 \% .\end{array}$ \\
\hline $\begin{array}{l}\text { Selective reporting (re- } \\
\text { porting bias) }\end{array}$ & Unclear risk & $\begin{array}{l}\text { The trial protocol is not available. It was unknown if outcomes were selectively } \\
\text { reported. }\end{array}$ \\
\hline $\begin{array}{l}\text { Other bias } \\
\text { Tigh risk }\end{array}$ & $\begin{array}{l}\text { The trial was supported by the pharmaceutical industry but failed to report the } \\
\text { role of the pharmaceutical company during the trial }\end{array}$
\end{tabular}

Santos 2009

\begin{tabular}{ll}
\hline Methods & RCT \\
& Length of follow-up: 7 days \\
\hline
\end{tabular}

Number: 179
Inclusion criteria:
Children aged 3 to 36 months with acute gastroenteritis
Exclusion criteria:
Patients requiring hospitalization, with more than 7 days of symptoms, allergic to any of the compo-
nents of the drug, and receiving drugs that may interact with racecadotril, such antibiotics, salicy-
lates, or other anti-diarrhoea drugs.
Missing data: 46 participants

Interventions Group 1: 88 received racecadotril additional to oral rehydration

Group 2: 91 received oral rehydration only

The doses of racecadotril were: $10 \mathrm{mg}$ every 8 hours for children weighing less than $9 \mathrm{~kg} ; 20 \mathrm{mg}$ every 8 hours for children weighing 9 to $13 \mathrm{~kg} ; 30 \mathrm{mg}$ every 8 hours for children weighing more than $13 \mathrm{~kg}$.

- Duration of diarrhoea.
- Number of bowel movements within 24 hours. Parents or caregivers were provided with a notebook
to record the time of each bowel movement.
- Number of bowel movements between 24 and 48 hours.
- Treatment adherence. Therapeutic adherence was evaluated based on the number of doses received
in 48 hours of treatment: good compliance was defined as when the patients received $75 \%$ or more
of doses according to the patient's weight.
- Adverse events.


Santos 2009 (Continued)

Supported by pharmaceutical company who provided funds for monitoring process, statistical analysis, and trial drugs.

The sponsor participated in the trial design but did not participate in the collection, analysis, or interpretation of data.

\section{Risk of bias}

\begin{tabular}{lll}
\hline Bias & Authors' judgement & Support for judgement \\
\hline $\begin{array}{l}\text { Random sequence genera- } \\
\text { tion (selection bias) }\end{array}$ & Low risk & $\begin{array}{l}\text { Randomization of each treatment group was performed using a computer pro- } \\
\text { gram, which creates a random number list, divided into 2 blocks, } 1 \text { for each } \\
\text { group }\end{array}$ \\
\hline $\begin{array}{l}\text { Allocation concealment } \\
\text { (selection bias) }\end{array}$ & Unclear risk & Not mentioned \\
\hline $\begin{array}{l}\text { Blinding of participants } \\
\text { and personnel (perfor- } \\
\text { mance bias) } \\
\begin{array}{l}\text { All outcomes } \\
\text { High risk }\end{array}\end{array}$ & No blinding \\
\hline
\end{tabular}

Blinding of outcome as-

High risk

No blinding

sessment (detection bias)

All outcomes

\begin{tabular}{|c|c|c|}
\hline $\begin{array}{l}\text { Incomplete outcome data } \\
\text { (attrition bias) } \\
\text { All outcomes }\end{array}$ & High risk & $\begin{array}{l}\text { Loss to follow-up was } 25.7 \% \text { (more than } 20 \% \text { ). The number of participants lost } \\
\text { to follow-up was balanced in two groups but it was not reported if the reasons } \\
\text { for loss to follow-up was also balanced in two groups. }\end{array}$ \\
\hline
\end{tabular}

\begin{tabular}{lll}
\hline $\begin{array}{l}\text { Selective reporting (re- } \\
\text { porting bias) }\end{array}$ & Unclear risk & The trial protocol is not available \\
\hline Other bias & Low risk & $\begin{array}{l}\text { The sponsor participated in the trial design but did not participate in the col- } \\
\text { lection, analysis, or interpretation of data. }\end{array}$
\end{tabular}

Sreenivas 2017

\begin{tabular}{ll}
\hline Methods & RCT \\
& Length of follow-up: not reported \\
\hline
\end{tabular}

Participants

Number: 117

Participants were hospitalized but those with severe dehydration were excluded

Inclusion criteria:

Patients aged between 3 months and 5 years with acute watery diarrhoea with duration fewer than 7 days were selected for the trial.

Exclusion criteria:

Subjects were excluded if they had persistent vomiting $>3$ episodes/h, severe dehydration, or any serious concomitant illness including HIV seropositive status and severe malnutrition, blood in stool, received an antibiotic or any antidiarrhoeal drug within the preceding 48 hours.

Missing data: 4 participants 
Sreenivas 2017 (Continued)

Interventions

Group 1: 55 received racecadotril additional to oral rehydration

Group 2: 62 received oral rehydration only

Racecadotril was given at a dose of $1.5 \mathrm{mg} / \mathrm{kg} /$ day 8 hourly. A uniform dose of $20 \mathrm{mg}$ of elemental zinc was given to all children in both the groups. All the subjects were given breastfeeding, milk and soft food in accordance with WHO recommendations that diet be maintained during treatment of diarrhoea to prevent nutritional disturbance.

\begin{tabular}{ll}
\hline Outcomes & - Stool frequency during first 48 hours \\
- Total volume of ORS consumed until the cure of diarrhoea & Time taken for a cure \\
- Tolerability
\end{tabular}

\begin{tabular}{ll}
\hline Notes & Location: India \\
& No funding received
\end{tabular}

\section{Risk of bias}

\begin{tabular}{|c|c|c|}
\hline Bias & Authors' judgement & Support for judgement \\
\hline $\begin{array}{l}\text { Random sequence genera- } \\
\text { tion (selection bias) }\end{array}$ & Low risk & $\begin{array}{l}\text { Simple random sampling was used to randomize the subjects into } 2 \text { groups by } \\
\text { computer-generated numbers }\end{array}$ \\
\hline $\begin{array}{l}\text { Allocation concealment } \\
\text { (selection bias) }\end{array}$ & Unclear risk & Not mentioned \\
\hline $\begin{array}{l}\text { Blinding of participants } \\
\text { and personnel (perfor- } \\
\text { mance bias) } \\
\text { All outcomes }\end{array}$ & High risk & No blinding \\
\hline $\begin{array}{l}\text { Blinding of outcome as- } \\
\text { sessment (detection bias) } \\
\text { All outcomes }\end{array}$ & High risk & No blinding \\
\hline $\begin{array}{l}\text { Incomplete outcome data } \\
\text { (attrition bias) } \\
\text { All outcomes }\end{array}$ & Low risk & $\begin{array}{l}\text { The loss to follow-up was balanced across the } 2 \text { groups, with } 2 / 55 \text { lost from } \\
\text { the intervention and } 2 / 62 \text { from the control group. Total attrition was less than } \\
20 \% \text {. }\end{array}$ \\
\hline $\begin{array}{l}\text { Selective reporting (re- } \\
\text { porting bias) }\end{array}$ & Unclear risk & $\begin{array}{l}\text { Registration of the protocol was not mentioned in the article and the trial pro- } \\
\text { tocol was not available. }\end{array}$ \\
\hline Other bias & Low risk & No funding from the pharmaceutical industry \\
\hline
\end{tabular}

Abbreviations: RCT: randomized controlled trial.

Characteristics of excluded studies [ordered by study ID]

\begin{tabular}{ll}
\hline Study & Reason for exclusion \\
\hline Calatayud 2009 & Observational study \\
\hline Chacón 2010 & Observational study \\
\hline
\end{tabular}




\begin{tabular}{|c|c|}
\hline Study & Reason for exclusion \\
\hline Cojocaru 2002 & Not an RCT \\
\hline Melendez-Garcia 2007 & The control agent is kaolin/pectin \\
\hline Michael 2014 & Observational study \\
\hline NCT03463512 & Children aged from 3 months to 17 years \\
\hline Rautenberg 2012 & Cost effectiveness study, not an RCT \\
\hline Tiholova 2010 & Only abstract available; observational study \\
\hline Torrez 2013 & Only abstract available. $52 \%$ failed to complete the treatment \\
\hline Turck 1999 & Racecadotril was compared with loperamide \\
\hline
\end{tabular}

Abbreviations: RCT: randomized controlled trial.

Characteristics of studies awaiting assessment [ordered by study ID]

ChicTR-TRC-12002199

\begin{tabular}{ll}
\hline Methods & RCT \\
\hline Participants & Children aged 2 to 36 months with acute watery diarrhoea \\
\hline Interventions & Racecadotril + rehydration therapy versus rehydration therapy only \\
\hline Outcomes & Duration of symptoms and signs; incidence of adverse reaction \\
\hline Notes & Conducted in China and data was not found \\
\hline
\end{tabular}

Gutiérrez-Castrellón 2010

\begin{tabular}{ll}
\hline Methods & RCT \\
\hline Participants & Infants aged 1 to 24 months with acute diarrhoea \\
\hline Interventions & Racecadotril \\
\hline Outcomes & $\begin{array}{l}\text { Stool output, duration of diarrhoea, percentage of need for intravenous fluids for rehydration, per- } \\
\text { centage of adverse events, frequency of stools/day, frequency of liquid or semi-liquid stools/day. }\end{array}$ \\
\hline Notes & Further information needed \\
\hline
\end{tabular}

\section{IRCT201607131264N8}

\begin{tabular}{ll}
\hline Methods & Randomized, open-label, parallel-group study \\
\hline Participants & Children aged 1 months to 5 years with acute diarrhoea
\end{tabular}




\section{IRCT201607131264N8 (Continued)}

Interventions

Serum therapy + racecadotril ( $1.5 \mathrm{mg}$ per $\mathrm{kg}$, 3 doses/day for 5 days or when no diarrhoea) versus serum therapy only

\section{Outcomes}

Duration of diarrhoea; frequency of diarrhoea; duration of hospital stay

\section{Conducted in Iran}

Data was not found

Savitha 2006

\begin{tabular}{ll}
\hline Methods & RCT \\
\hline Participants & Children aged 3 to 60 months with acute diarrhoea \\
\hline Interventions & Racecadotril + rehydration therapy versus placebo + rehydration therapy \\
\hline Outcomes & Diarrhoea duration \\
\hline Notes & Data was not found \\
\hline
\end{tabular}

Abbreviations: RCT: randomized controlled trial.

\section{DATA AND ANALYSES}

\section{Comparison 1. Racecadotril versus placebo/no treatment}

\begin{tabular}{lllll}
\hline Outcome or subgroup title & $\begin{array}{l}\text { No. of } \\
\text { studies }\end{array}$ & $\begin{array}{l}\text { No. of } \\
\text { partici- } \\
\text { pants }\end{array}$ & Statistical method & Effect size \\
\hline 1 Failure of rehydration & 2 & 192 & Risk Ratio (M-H, Fixed, 95\% CI) & $0.41[0.13,1.23]$ \\
\hline 2 Number of stools within 24 hours & 2 & 258 & $\begin{array}{l}\text { Mean Difference (IV, Fixed, 95\% } \\
\text { Cl) }\end{array}$ & $-0.24[-0.90,0.43]$ \\
\hline 3 Number of stools between 24 to 48 hours & 2 & 258 & $\begin{array}{l}\text { Mean Difference (IV, Random, } \\
95 \% \text { Cl) }\end{array}$ & $-0.80[-1.87,0.27]$ \\
\hline 4 Stool output within 24h & 1 & 167 & $\begin{array}{l}\text { Mean Difference (IV, Fixed, 95\% } \\
\text { Cl) }\end{array}$ & $-5.5[-7.71,-3.29]$ \\
\hline 5 Stool output within 48h & 2 & & $\begin{array}{l}\text { Std. Mean Difference (IV, Fixed, } \\
95 \% \text { Cl) }\end{array}$ & Subtotals only \\
\hline $\begin{array}{l}\text { 5.1 Stool output within 48 hours (all patients) } \\
\text { tavirus-positive patients) }\end{array}$ & 2 & 301 & $\begin{array}{l}\text { Std. Mean Difference (IV, Fixed, } \\
95 \% \text { Cl) }\end{array}$ & $-0.65[-0.88,-0.41]$ \\
\hline
\end{tabular}




\begin{tabular}{lllll}
\hline Outcome or subgroup title & $\begin{array}{l}\text { No. of } \\
\text { studies }\end{array}$ & $\begin{array}{l}\text { No. of } \\
\text { partici- } \\
\text { pants }\end{array}$ & Statistical method & Effect size \\
\hline 6 Adverse events & 5 & 688 & $\begin{array}{l}\text { Risk Ratio (M-H, Random, 95\% } \\
\mathrm{Cl})\end{array}$ & $0.90[0.66,1.22]$ \\
\hline
\end{tabular}

Analysis 1.1. Comparison 1 Racecadotril versus placebo/no treatment, Outcome 1 Failure of rehydration.

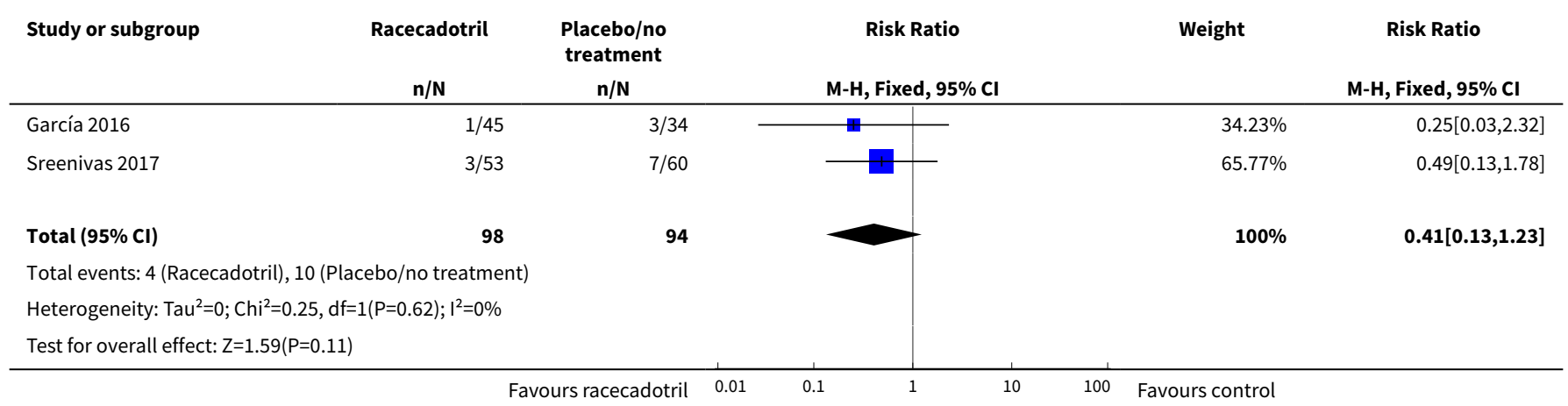

Analysis 1.2. Comparison 1 Racecadotril versus placebo/ no treatment, Outcome 2 Number of stools within 24 hours.

\begin{tabular}{|c|c|c|c|c|c|c|c|}
\hline \multirow{3}{*}{$\begin{array}{l}\text { Study or subgroup } \\
\text { García } 2016\end{array}$} & \multicolumn{2}{|c|}{ Racecadotril } & \multicolumn{2}{|c|}{$\begin{array}{l}\text { Placebo/no } \\
\text { treatment }\end{array}$} & \multirow{2}{*}{$\begin{array}{c}\text { Mean Difference } \\
\text { Fixed, } 95 \% \mathrm{Cl} \\
\end{array}$} & \multirow[t]{2}{*}{ Weight } & \multirow{2}{*}{$\begin{array}{c}\text { Mean Difference } \\
\text { Fixed, } 95 \% \mathrm{Cl} \\
\end{array}$} \\
\hline & $\mathbf{N}$ & Mean(SD) & $\mathbf{N}$ & Mean(SD) & & & \\
\hline & 45 & $4.1(2.6)$ & 34 & $5.1(3.4)$ & 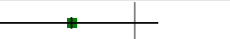 & $23.61 \%$ & $-1[-2.37,0.37]$ \\
\hline Santos 2009 & 88 & $4.6(2.7)$ & 91 & $4.6(2.5)$ & & $76.39 \%$ & $0[-0.76,0.76]$ \\
\hline Total $* \star \star$ & 133 & & 125 & & & $100 \%$ & $-0.24[-0.9,0.43]$ \\
\hline \multicolumn{8}{|c|}{ Test for overall effect: $Z=0.69(P=0.49)$} \\
\hline
\end{tabular}

Analysis 1.3. Comparison 1 Racecadotril versus placebo/no treatment, Outcome 3 Number of stools between 24 to 48 hours.

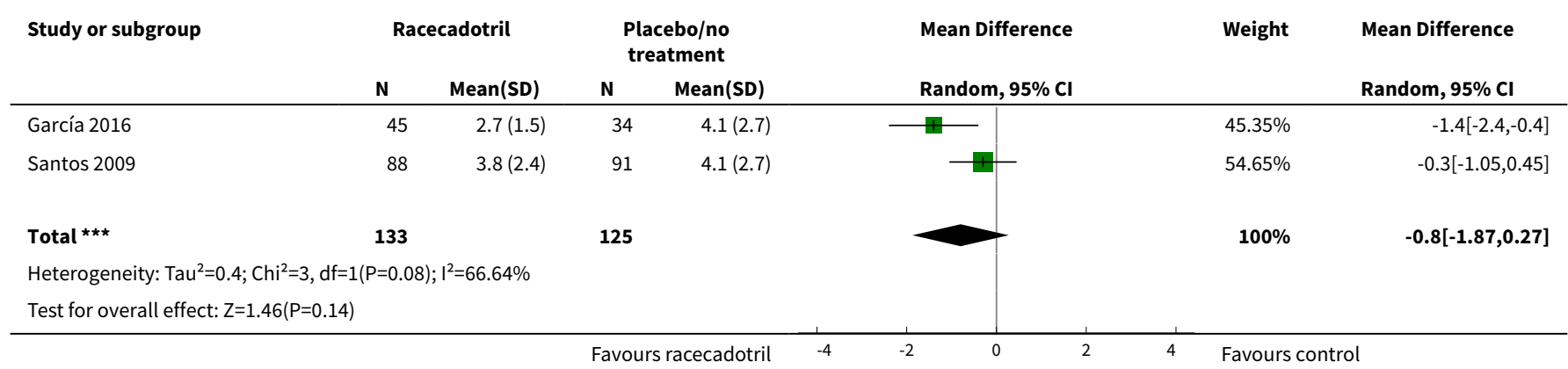


Analysis 1.4. Comparison 1 Racecadotril versus placebo/no treatment, Outcome 4 Stool output within $24 \mathrm{~h}$.

\begin{tabular}{|c|c|c|c|c|c|c|c|}
\hline \multirow[t]{2}{*}{ Study or subgroup } & \multicolumn{2}{|c|}{ Racecadotril } & \multicolumn{2}{|c|}{$\begin{array}{l}\text { Placebo/no } \\
\text { treatment }\end{array}$} & \multirow{2}{*}{$\begin{array}{c}\text { Mean Difference } \\
\text { Fixed, } 95 \% \mathrm{Cl}\end{array}$} & \multirow[t]{2}{*}{ Weight } & \multirow{2}{*}{$\begin{array}{l}\text { Mean Difference } \\
\text { Fixed, } 95 \% \mathrm{Cl}\end{array}$} \\
\hline & $\mathbf{N}$ & Mean(SD) & $\mathbf{N}$ & Mean(SD) & & & \\
\hline Cézard 2001 & 85 & $10.5(7.4)$ & 82 & $16(7.2)$ & + & $100 \%$ & $-5.5[-7.71,-3.29]$ \\
\hline Total $\star^{\star \star \star}$ & 85 & & 82 & & $\rightarrow$ & $100 \%$ & $-5.5[-7.71,-3.29]$ \\
\hline \multicolumn{8}{|c|}{ Heterogeneity: Not applicable } \\
\hline Test for overall effec & & & & & & & \\
\hline
\end{tabular}

\section{Analysis 1.5. Comparison 1 Racecadotril versus placebo/no treatment, Outcome 5 Stool output within $48 \mathrm{~h}$.}

\begin{tabular}{|c|c|c|c|c|c|c|c|}
\hline \multirow[t]{2}{*}{ Study or subgroup } & \multicolumn{2}{|c|}{ Racecadotril } & \multicolumn{2}{|c|}{$\begin{array}{c}\text { Placebo/no } \\
\text { treatment }\end{array}$} & \multirow{2}{*}{$\begin{array}{l}\text { Std. Mean Difference } \\
\qquad \text { Fixed, } 95 \% \mathrm{Cl}\end{array}$} & \multirow[t]{2}{*}{ Weight } & \multirow{2}{*}{$\begin{array}{l}\text { Std. Mean Difference } \\
\text { Fixed, } 95 \% \mathrm{Cl} \\
\end{array}$} \\
\hline & $\mathbf{N}$ & Mean(SD) & $\mathbf{N}$ & Mean(SD) & & & \\
\hline \multicolumn{8}{|c|}{ 1.5.1 Stool output within 48 hours (all patients) } \\
\hline Cézard 2001 & 84 & $9.3(11)$ & 82 & $15.2(8.1)$ & + & $55.5 \%$ & $-0.61[-0.92,-0.3]$ \\
\hline Salazar-Lindo 2000 & 68 & $92(99)$ & 67 & $170(122.8)$ & - & $44.5 \%$ & $-0.7[-1.04,-0.35]$ \\
\hline 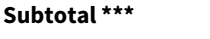 & 152 & & 149 & & & $100 \%$ & $-0.65[-0.88,-0.41]$ \\
\hline \multicolumn{8}{|c|}{ Test for overall effect: $Z=5.46(P<0.0001)$} \\
\hline \multicolumn{8}{|c|}{ 1.5.2 Stool output within 48 hours (rotavirus-positive patients) } \\
\hline Cézard 2001 & 24 & $8.5(7.8)$ & 31 & $19.4(14.5)$ & + & $42.14 \%$ & $-0.89[-1.45,-0.33]$ \\
\hline Salazar-Lindo 2000 & 34 & $105(99)$ & 39 & 195 (124.9) & & $57.86 \%$ & $-0.78[-1.26,-0.31]$ \\
\hline Subtotal $\star \star \star ~$ & 58 & & 70 & & & $100 \%$ & $-0.83[-1.19,-0.47]$ \\
\hline \multicolumn{8}{|c|}{ Test for overall effect: $Z=4.47(P<0.0001)$} \\
\hline Test for subgroup dif & $59, \mathrm{df}=$ & $P=0.41), I^{2}=0$ & & & & & \\
\hline
\end{tabular}

Analysis 1.6. Comparison 1 Racecadotril versus placebo/no treatment, Outcome 6 Adverse events.

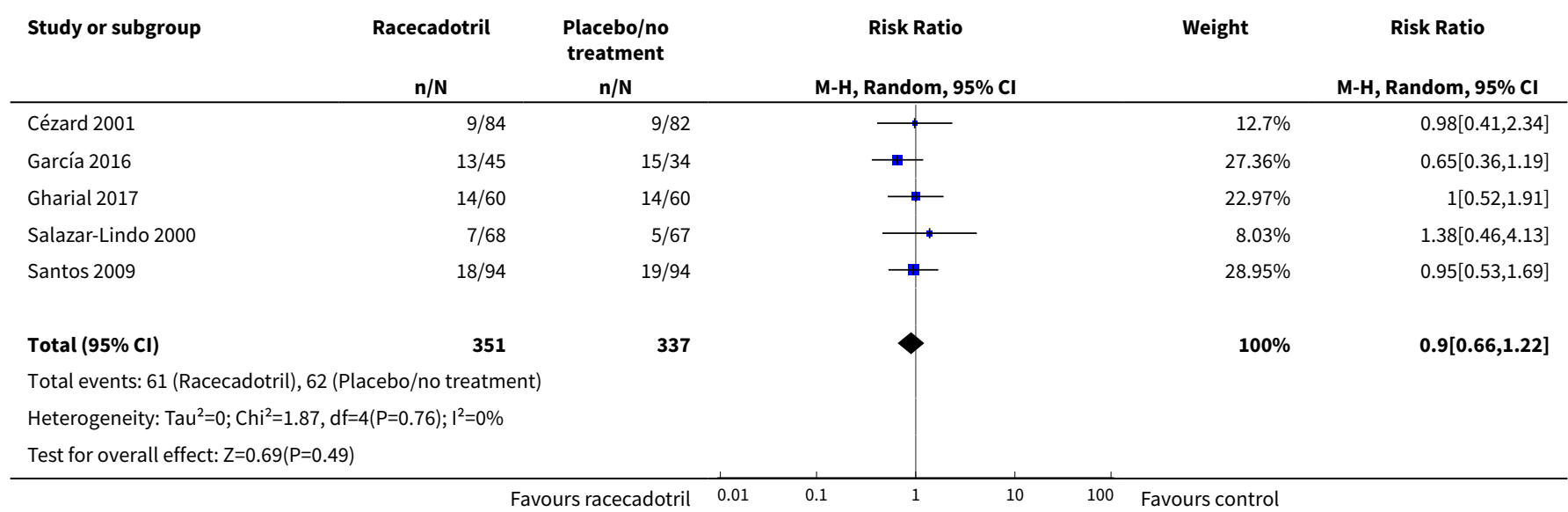


ADDITIONAL TABLES

Table 1. Average duration of diarrhoea in two groups (Continued)

\begin{tabular}{|c|c|c|c|c|c|}
\hline \multirow[t]{2}{*}{ Group } & \multirow[t]{2}{*}{ Trial } & \multirow{2}{*}{$\begin{array}{l}\text { Number } \\
\text { of partici- } \\
\text { pants }\end{array}$} & \multicolumn{2}{|c|}{ Duration of diarrhoea (days) } & \multirow[t]{2}{*}{$P$ value } \\
\hline & & & Racecadotril & Control & \\
\hline \multirow{2}{*}{$\begin{array}{l}\text { Outpa- } \\
\text { tients }\end{array}$} & Santos 2009 & 179 & $4.0(2.1)^{a}$ & $4.7(2.2)^{a}$ & 0.15 \\
\hline & Kang 2016b & 196 & $2(2,4)^{b}$ & $2(2,4)^{b}$ & 0.88 \\
\hline \multirow[t]{7}{*}{ Inpatients } & Salazar-Lindo 2000 & 73 & $1.2^{\mathrm{C}}$ & $2.2^{c}$ & $<0.001$ \\
\hline & (rotavirus-positive) & & & & \\
\hline & Salazar-Lindo 2000 & 62 & $1.2^{\mathrm{C}}$ & $3 c$ & $<0.001$ \\
\hline & (rotavirus-negative) & & & & \\
\hline & Gharial 2017 & 120 & $3(2,4)^{b}$ & $2(1,3)^{b}$ & 0.77 \\
\hline & Kang 2016a & 124 & $1.1(0.6,1.8)^{b}$ & $1.0(0.7,1.9)^{\mathrm{b}}$ & 0.57 \\
\hline & Sreenivas 2017 & 113 & $1.6(0.3)^{a}$ & $2.1(0.6)^{a}$ & $<0.001$ \\
\hline
\end{tabular}

a Mean (standard deviation).

bMedian (interquartile range).

cMedian without reporting interquartile range.

\section{APPENDICES}

\section{Appendix 1. Search strategy}

\begin{tabular}{|c|c|c|c|c|c|}
\hline $\begin{array}{l}\text { Search } \\
\text { set }\end{array}$ & CIDG SR 1 & CENTRAL & MEDLINE2 & Embase $^{2}$ & LILACS 2 \\
\hline 1 & Diarrh* & Diarrh* ti, ab & Diarrh $^{\star}$ ti, ab & Diarrh $^{\star}$ ti, ab & Diarrh\$ \\
\hline 2 & Racecadotril $^{\star}$ & $\begin{array}{l}\text { Diarrhea/drug therapy } \\
{[\mathrm{MeSH}]}\end{array}$ & $\begin{array}{l}\text { Diarrhea/drug therapy } \\
{[\mathrm{MeSH}]}\end{array}$ & Diarrhea [Emtree] & $\begin{array}{l}\text { Racecadotril } \\
\$\end{array}$ \\
\hline 3 & Child $^{*}$ & Gastroenteritis ti, ab & Gastroenteritis ti, ab & $\begin{array}{l}\text { Acute gastroenteritis } \\
\text { [Emtree] }\end{array}$ & Child\$ \\
\hline 4 & Infant ${ }^{\star}$ & Racecadotril $^{\star}$ & Racecadotril $^{\star}$ & Racecadotril $^{\star}$ & Infant\$ \\
\hline 5 & Paediatr* & $\begin{array}{l}\text { Thiorphan/analogs \& de- } \\
\text { rivatives/ }\end{array}$ & $\begin{array}{l}\text { Thiorphan/analogs \& de- } \\
\text { rivatives/ }\end{array}$ & Acetorphan [Emtree] & Paediatr\$ \\
\hline 6 & Pediatr ${ }^{\star}$ & Child $^{*}$ & Child $^{*}$ & Child $^{\star}$ & Pediatr\$ \\
\hline
\end{tabular}




\begin{tabular}{|c|c|c|c|c|c|}
\hline 7 & Toddler* & Infant* & Infant* & Infant* & Toddler\$ \\
\hline 8 & $3-7 / O R$ & Toddler* & Toddler* & Toddler* & $3-7 / O R$ \\
\hline 9 & $\begin{array}{l}1 \text { AND } 2 \text { AND } \\
8\end{array}$ & Pediatr* & Pediatr* & Pediatr* & $\begin{array}{l}1 \text { AND } 2 \text { AND } \\
8\end{array}$ \\
\hline 10 & - & Paediatr* & Paediatr* & Paediatr* & - \\
\hline 11 & - & 1 OR 2 OR 3 & 1 OR 2 OR 3 & 1 OR 2 OR 3 & - \\
\hline 12 & - & 4 OR 5 & 4 OR 5 & 4 OR 5 & - \\
\hline 13 & - & $6-10 / O R$ & $6-10 / O R$ & $6-10 / O R$ & - \\
\hline 14 & - & 11 AND 12 AND 13 & 11 AND 12 AND 13 & 11 AND 12 AND 13 & - \\
\hline
\end{tabular}

${ }^{1}$ Cochrane Infectious Diseases Group Specialized Register.

2Search terms used in combination with the search strategy for retrieving trials developed by the Cochrane Collaboration (Lefebvre 2011).

\section{CONTRIBUTIONS OF AUTHORS}

Lingli Zhang and Yi Liang conceived and designed the review.

Yi Liang and Morris Gordon searched and obtained data, and wrote and revised the review.

Yi Liang and Linan Zeng performed study selection and data extraction.

Yi Liang and Jin Wen analyzed the data.

All review authors read and approved the final review version.

\section{DECLARATIONS OF INTEREST}

Yi Liang has no known conflicts of interest.

Lingli Zhang has no known conflicts of interest.

Linan Zeng has no known conflicts of interest.

Since August 2016, Morris Gordon has received travel fees to attend international scientific and training meetings such as DDW (May 2017, 2018, and 2019), Advances in IBD (December 2018), and World Congress of Gastroenterology (October 2017) from companies including: Biogaia (2017-19), Ferring (2018), Allergan (2017), Synergy (bankrupt - 2018) and Tillots (2017-19). None of these companies have had any involvement in any works completed by MG.

Jin Wen has no known conflicts of interest.

\section{SOURCES OF SUPPORT}

\section{Internal sources}

- Sichuan University, China.

- Liverpool School of Tropical Medicine, UK.

- The University of Texas at Austin, USA.

\section{External sources}

- Department for International Development (DFID), UK.

Project number 300342-104 


\section{DIFFERENCES BETWEEN PROTOCOL AND REVIEW}

In the published protocol, Liang 2011, we stated that we intended to include trials from Chinese databases in the efficacy assessment. However, as those articles are potentially at higher risk of bias, we decided to exclude trials published in those databases.

We also planned to include quasi-RCTs, but we excluded these from the full review as more RCTs have been published and quasi-RCTs might be subject to higher risk of bias.

We planned to search the Index to the Index to Scientific \& Technical Proceedings (ISTP) for conference abstracts, but this database became unavailable to us after protocol publication.

We used the GRADE approach to assess the certainty of the evidence and constructed 'Summary of findings' tables and conducted ITT analyses for sensitivity analysis for dichotomous outcomes in the review. 